\title{
Analisis Nilai Penting Situs-Situs di Kawasan Cagar Budaya Borobudur
}

\section{Statement of Significance for Archaeological Sites within Borobudur Cultural Area}

\author{
Panggah Ardiyansyah \\ Balai Konservasi Borobudur \\ panggah.ardiyansyah@kemdikbud.go.id
}

\begin{abstract}
ABSTRAK
Penetapan kawasan Borobudur sebagai Cagar Budaya Peringkat Nasional melalui Keputusan Menteri Pendidikan dan Kebudayaan Nomor 286/M/2014 tentang Satuan Ruang Geografis Borobudur sebagai Kawasan Cagar Budaya Peringkat Nasional sayangnya masih belum didahului dengan kajian yang mendalam tentang situs-situs selain Candi Borobudur, Candi Mendut dan Candi Pawon yang termasuk didalam zonasi yang telah ditetapkan sebagai Kawasan Cagar Budaya (KCB) Borobudur. Tujuan tulisan ini adalah untuk mendiskusikan nilai penting situs-situs di KCB dengan ruang lingkupnya adalah Lokasi Yoni Brongsongan, Lokasi Candi Dipan, Lokasi Candi Bowongan, Lokasi Candi Samberan, Lokasi Yoni di Plandi, dan Lokasi Makam Belanda (Kerkhoff) Bojong di Mendut. Metode pengkajian dilakukan melalui pengumpulan data historis dan arkeologis, penempatan data-data tersebut dalam konteksnya masing-masing, dan komparasi dengan situs serupa apabila diperlukan. Hasil analisis menunjukan kehadiran nilai penting bagi sejarah, ilmu pengetahuan, agama dan kebudayaan. Keberadaan nilai penting ini memberikan keterkaitan antara nilai penting kawasan Borobudur dalam level internasioal, nasional dan lokal, sehingga pelestariannya perlu memperhatikan suara masyarakat lokal di kawasan Borobudur.
\end{abstract}

Kata Kunci: nilai penting; kawasan cagar budaya; Borobudur; lansekap budaya; ekologi budaya

\begin{abstract}
The designation of Borobudur landscape as a National Cultural Area by the Decree of Minister of Education and Culture Number 286/M/2014 regarding Geographical Boundaries of Borobudur as National Cultural Area (hereafter KCB Borobudur) was not preceded by in-depth study on sites other than Borobudur Temple, Mendut Temple and Pawon Temple. The objective of this paper is to discuss and analyze the significance of each site within KCB Borobudur. The paper's scope includes Yoni Brongsongan, Dipan Temple, Bowongan Temple, Samberan Temple, Yoni Plandi, and Dutch Cemeteries (Kerkhoff) Bojong in Mendut, which are included in KCB Borobudur. The methodology includes collecting data, giving contexts to each data set, and comparing to other similar sites if required. The analysis shows the significance of the sites for history, sciences, religions, and culture. These statements correlates the significance of Borobudur area in international, national, dan local levels, thus giving emphasis on the need to include local voices in the preservation of $\mathrm{KCB}$ Borobudur.
\end{abstract}


Keywords: statement of significance; cultural heritage area; Borobudur; cultural landscape; cultural ecology

\section{PENDAHULUAN}

Candi Borobudur telah ditetapkan sebagai Warisan Dunia oleh UNESCO pada tahun 1991, bersama dengan Candi Mendut dan Pawon, dengan nama resmi Borobudur Temple Compounds. Kompleks percandian ini dianggap memenuhi tiga kriteria Nilai Universal Luar Biasa, yaitu

- Kriteria (i), karena dengan strukturnya yang berbentuk piramida berundak tanpa atap dengan 10 teras keatas, dan dipuncaknya terdapat kubah berbentuk genta besar, merupakan sebuah perpaduan yang harmonis dari stupa, candi dan gunung, sehingga dapat dianggap sebagai mahakarya arsitektur Buddhis dan seni monumental;

- Kriteria (ii), karena merupakan contoh luar biasa dari seni dan arsitektur Indonesia yang berasal dari antara awal abad kedelapan dan akhir abad kesembilan yang memberikan pengaruh besar terhadap kebangkitan arsitektural pada abad ke-13 dan awal abad ke16.

- Kriteria (vi), karena strukturnya yang berbentuk teratai, bunga pemujaan Buddha, Candi Borobudur merupakan sebuah refleksi luar biasa dari perpaduan ide dasar pemujaan roh leluhur dan konsep Buddha menuju Nirwana, sehingga 10 terasnya menggambarkan tahapan bagi Boddhisatwa dalam mencapai keBuddha-an.

(http://whc.unesco.org/en/list/592)
Dalam perjalanannya sebagai situs Warisan Dunia, Borobudur Temple Compounds menghadapi berbagai ancaman, terutama dari pembangunan yang dapat mengancam hubungan antara monumen utama dengan lingkungan disekitarnya. Ancaman ini diakibatkan oleh lemahnya regulasi pengembangan kawasan, sehingga, menanggapi ancaman ini, pemerintah kemudian mengeluarkan Peraturan Presiden Nomor 58 Tahun 2014 tentang Rencana Tata Ruang Kawasan Borobudur dan Sekitarnya, yang telah ditetapkan sebagai Kawasan Strategis Nasional (KSN) melalui Peraturan Pemerintah Nomor 26 Tahun 2008 tentang Tata Ruang Wilayah Nasional. Selain itu, kompleks percandian dan kawasannya juga mendapatkan tekanan dari kegiatan pariwisata serta ancaman bencana alam seperti letusan gunung berapi. Tingkat keterawatan material batu juga harus terus dipantau untuk mengontrol tingkat pelapukannya.

Sementara itu, pada tahun 2010, pemerintah Indonesia mengeluarkan peraturan perundangan baru tentang cagar budaya, yaitu Undang-Undang Nomor 11 Tahun 2010 tentang Cagar Budaya, karena perundangan yang lama dinilai telah tidak sesuai dengan perkembangan zaman. Dalam perundangan yang baru ini, cagar budaya harus ditetapkan berdasarkan peringkat kabupaten/ kota, provinsi dan nasional oleh tim ahli cagar budaya di masing-masing tingkatan. 
Mengingat bahwa setiap situs Warisan Dunia yang ditetapkan oleh UNESCO harus berstatus sebagai cagar budaya nasional, maka secara retrospektif, Candi Borobudur, Mendut dan Pawon beserta kawasannya ditetapkan sebagai Kawasan Cagar Budaya Peringkat Nasional melalui Keputusan Menteri Pendidikan dan Kebudayaan Nomor 286/M/2014 tentang Satuan Ruang Geografis Borobudur sebagai Kawasan Cagar Budaya Peringkat Nasional. Dalam peraturan tersebut, disebutkan bahwa dalam satuan ruang geografis Borobudur (selanjutnya disebut sebagai KCB Borobudur) terdapat:

1. Situs Candi Borobudur

2. Situs Candi Mendut

3. Situs Candi Pawon

4. Situs Candi Ngawen

5. Lokasi Yoni Brongsongan

6. Lokasi Candi Dipan

7. Lokasi Candi Bowongan

8. Lokasi Candi Samberan

9. Lokasi Yoni di Plandi

10. Lokasi Makam Belanda (Kerkhoff) Bojong di Mendut Sejalan dengan ancaman terhadap kompleks percandian di Borobudur sebagai situs Warisan Dunia, keputusan tersebut juga menyampaikan bahwa satuan ruang geografis Borobudur terdesak oleh perubahan tata guna lahan, yaitu perkembangan pemukiman, dan pertumbuhan bangunan dikarenakan beralihnya mata pencaharian penduduk dari sektor pertanian ke sektor barang dan/atau jasa, banyaknya menara Base Transceiver Station (BTS) yang dapat merusak integritas visual lansekap dan pertumbuhan jumlah wisatawan. Maka berdasarkan berbagai ancaman ini, zonasi satuan ruang geografis
Borobudur sebagai cagar budaya peringkat nasional ditetapkan mengikuti zonasi kawasan Borobudur yang telah ditetapkan sebagai KSN Borobudur yang bertujuan untuk mengontrol perkembangan dan perubahan kawasan Borobudur untuk tetap memiliki karakter pedesaan. Sementara itu, status kepemilikan dan pengelolaan KCB Borobudur dibagi menjadi empat, yaitu zona I Candi Borobudur dimiliki dan dikelola oleh Kementerian Pendidikan dan Kebudayaan melalui Balai Konservasi Borobudur, zona II dimiliki oleh Kementerian BUMN dan dikelola oleh PT Taman Wisata Candi Borobudur, Prambanan dan Ratu Boko, zona III dikelola oleh pemerintah daerah Kabupaten Magelang serta dimiliki dan/atau dikuasai oleh masyarakat setempat.

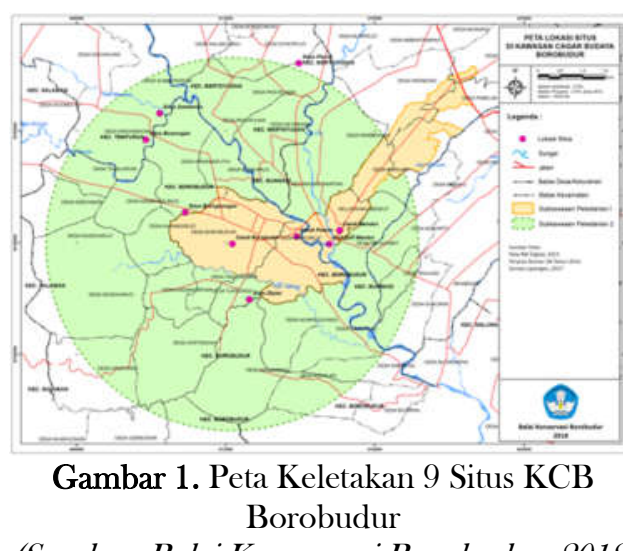

(Sumber: Balai Konservasi Borobudur, 2018)

Dari kesepuluh situs yang berada didalam KCB Borobudur, Candi Borobudur, Mendut, Pawon dan Ngawen telah memiliki zonasi sendiri, sehingga dapat mengurangi ancaman perubahan tata guna lahan dan pemukiman yang dapat mengurangi tingkat kelestariannya. Sementara 6 situs lainnya masingmasing belum memiliki zonasi yang membuatnya rentan terhadap 
berbagai perubahan sosial dan ekonomi yang dapat mengancam keterawatan masing-masing situs. Oleh karena itu, penyusunan nilai penting dan strategi pelestarian dari Lokasi Yoni Brongsongan, Lokasi Candi Dipan, Lokasi Candi Bowongan, Lokasi Candi Samberan, Lokasi Yoni di Plandi, dan Lokasi Makam Belanda (Kerkhoff) Bojong di Mendut dirasa penting untuk dilakukan sehingga dapat menjadi dasar bagi konsep perencanaan $\mathrm{KCB}$ Borobudur kedepannya.

\section{RUMUSAN MASALAH}

1. Bagaimana karakteristik arkeologis dan historis dari enam situs di KCB Borobudur?

2. Bagaimana penjabaran nilai penting bagi sejarah, ilmu pengetahuan, pendidikan, agama, dan kebudayaan dari enam situs di KCB Borobudur?

3. Apa pendekatan strategi pelestarian yang sesuai bagi enam situs tersebut berdasarkan nilai pentingnya dan posisinya sebagai bagian dari KCB Borobudur?

\section{METODE}

Penelitian ini menggunakan metode kajian kualitatif dengan pendekatan historis dan arkeologis. Setiap situs dalam lingkup kajian dijabarkan dan digambarkan melalui deskripsi. Pendekatan historis digunakan untuk melihat perkembangan pelestarian dan kajian yang telah dilaksanakan di masingmasing situs, sedangkan pendekatan arkeologis dimanfaatkan untuk memberikan deskripsi temuan dan artefak di setiap situs. Proses pengambilan data dilakukan dengan kajian pustaka, penelusuran arsip, survei lapangan di setiap situs, wawancara dengan masyarakat sekitar dan pemilik bidang tanah situs dan ekskavasi di Lokasi Candi Dipan.

Pearson dan Sullivan (1995: 126) mengatakan bahwa dalam penilian nilai penting budaya, pertama ditentukan terlebih dahulu elemen-elemen cagar budaya yang membuatnya menjadi penting untuk dilestarikan, baru setelahnya menentukan tingkat setiap nilai penting yang telah dirumuskan. Maka dari itu, setelah informasi mengenai cagar budaya telah terkumpul dengan lengkap, setiap elemen cagar budaya harus dilihat konteksnya, baik secara historis, kebudayaan, dan sebagainya (Pearson dan Sullivan, 1995: 131). Apabila diperlukan, analisa komparatif dilakukan dengan situs lain yang memiliki kemiripan karakteristik (Ibid.).

\section{TINJAUAN PUSTAKA}

Tinggalan budaya (atau heritage) merupakan proses dan aktivitas kultural yang saat ini dilakukan pada dan di sekitar benda yang dianggap berharga dan bermakna, dimana proses dan aktivitas ini kemudian menjadi bagian tidak terpisahkan dari pemaknaan cagar budaya, yang merefleksikan nilai, debat, dan aspirasi kultural dan sosial kontemporer (Smith, 2006: 3). Lebih lanjut, cagar budaya tidak menjadi bernilai karena sifat intinstriknya, tetapi lebih kepada kerena cagar budaya mendapatkan nilai dan makna yang diberikan oleh manusia (Pearson and Sullivan, 1995: 21). Oleh karena itu, salah satu hal yang perlu ditekankan adalah bahwa pengkajian nilai penting selalu mempunyai unsur subyektifitas didalamnya sehingga interpretasi 
masa lalu 'yang benar' tidak mungkin dihasilkan (Ibid.: 168). Selain itu, nilai penting juga bersifat dinamis dan dapat berubah sesuai relasinya dengan unsur waktu dan tempat (Ibid.: 170).

Berkaitan dengan refleksi tersebut, maka dapat dikatakan bahwa kajian ini juga merupakan bentuk dari institusionalisasi pemaknaan cagar budaya, dimana selanjutnya situs-situs yang dikaji akan menjadi modal kultural yang dimiliki oleh negara. Sementara itu, satu-satunya alasan utama untuk melakukan pelestarian adalah ketika cagar budaya dimaknai melalui atribut historis, estetis dan sosial oleh elemen-elemen masyarakat, oleh seluruh elemen masyarakat, atau oleh negara (Pearson and Sullivan, 1995: 11). Dengan kesadaran bahwa institusionalisasi ini merupakan proses yang tidak dapat terhindarkan, maka perhatian khusus harus diberikan kepada nilai spesial cagar budaya bagi kelompok minoritas didalam masyarakat, yang merupakan hal yang tidak terpisahkan bagi nilai sosial suatu situs. Hal ini dilakukan karena dalam praktik pelestarian cagar budaya, nilai ini sering dipinggirkan atau tidak dianggap penting oleh budaya mayoritas serta kecenderungan untuk terlalu berfokus kepada aspek fisik yang kemudian menjadi representasi identitas bangsa (Pearson and Sullivan, 1995: 19; Smith 2006: 4). Sebagai akibat marginalisasi ini, pengalaman kultural dan sosial dari masyarakat lokal, secara problematik, tidak dianggap sehingga peran sosial, kultural dan/atau politis dari mereka terhadap tinggalan budaya pada masa sekarang seringkali diabaikan atau dianggap sepele (Smith, 2006: 36).
Maka dari itu, sedari awal program pelestarian harus melibatkan semua lapisan masyarakat secara aktif dan secara serius mendokumentasikan narasi masa kini yang diceritakan melalui cagar budaya (Holtorf, 2014: 3365).

Dari konsepsi teoritis tersebut, kajian ini akan memandang situs-situs didalam KCB Borobudur sebagai bukti fisik yang tidak dapat berdiri sendiri namun dalam kesatuan untuk memaknai lansekap kuno Borobudur sebagai bagian dari sejarah kuno Jawa di lembah Progo. Dikelilingi oleh pegunungan dan perbukitan, kawasan ini mempunyai densitas keberadaan candi yang tinggi, walaupun masih lebih rendah apabila dibandingkan dengan densitas di Kabupaten Sleman (Degroot, 2009: 74). Konsentrasi situs candi di lembah Progo ini berada di bagian selatan dimana Borobudur termasuk didalamnya, walaupun tampaknya masih terdistribusi secara acak (Degroot, 2009: 74-5). Sementara itu, dari observasi keberadaan situs candi di Jawa, dapat disimpulkan bahwa candi sering dibangun mengikuti aliran sungai, dimana keduanya memberikan manfaat bagi masingmasing, dengan keberadaan candi yang dapat menyucikan air sungai sedangkan air sungai menjadi sakral dengan kehadiran candi disampingnya (Degroot, 2009: 113 dan 119). Hal ini juga terlihat di KCB Borobudur dimana beberapa struktur bata dan yoni berada dekat dengan aliran sungai.

Beberapa kajian telah dilakukan yang berkaitan dengan persebaran situs-situs dari masa Hindu-Buddha di sekitar kawasan Borobudur. Tinjauan terhadap kajian-kajian ini dapat memberikan 
konteks makro kawasan bagi kajian ini yang mempunyai ruang lingkup yang lebih kecil. Pada tahun 2000, Wiwit Kasiyati dkk melaksanakan kajian berjudul Studi Isu Arkeologi pada Candi Borobudur. Kajian ini mempunyai tujuan untuk menggali informasi mengenai beberapa masalah atau isu yang sudah dikenali sebelum pemugaran tahun 19731983, yaitu keaslian chattra sebagai kemuncak stupa induk, makna bentuk stupa teras pada lantai 8, 9, dan 10, pagar dan patok batas halaman candi, koleksi arca lepas di Museum Borobudur, sisa-sisa bangunan vihara di halaman barat laut Candi Borobudur dan temuan arca Dwarapala di Bukit Dagi, serta pemasangan batu berelief yang salah penempatannya. Sebagai bagian dari pengumpulan data untuk menjawab pertanyaan penelitian tentang koleksi arca lepas di Museum Borobudur, Kasiyati dkk melakukan observasi lapangan ke candi-candi di sekitar Borobudur berdasarkan laporan temuan Proyek Pemugaran Candi Borobudur dan ROD tahun 1914. Dari observasi tersebut, didapatkan pendataan temuan dari 15 lokasi yang kemudian menyimpulkan bahwa di lokasi tersebut terdapat candi-candi yang berasal dari material bata, dengan material arca bisa berasal dari bata maupun batu.

Tahun 2002, penelitian arkeologi berjudul Pusat-Pusat Budaya Masa Lampau di Jawa Tengah: Kawasan Sekitar Borobudur sebagai Pusat Budaya Masa Klasik dilaksanakan oleh Baskoro Daru Tjahjono, T.M. Rita Istari dan T.M. Hari Lelono. Penelitian ini bertujuan untuk mengidentifikasi lokasi pusat Kerajaan Mataram Kuna, khususnya di kawasan sekitar Borobudur.
Metode yang digunakan adalah dengan mengidentifikasi persebaran situs-situs arkeologis masa Mataram Kuna di wilayah Dataran Kedu yang berkaitan dengan adaptasi lingkungan dan aspek sosial. Survei lapangan mengidentifikasi 48 situs yang terletak di Kabupaten Magelang, dimana 30 situs candi terbuat dari bata dan 18 situs candi terbuat dari batu andesit. Sebagian besar situs candi ini terkonsentrasi dalam radius $15 \mathrm{~km}$ dari Candi Borobudur. Sementara itu, berdasarkan ketinggian tempatnya, persebaran situs dapat dibagi dalam tiga kategori, yaitu ketinggian 200-400 mdpl sebanyak 36 situs, ketinggian 401-600 $\mathrm{mdpl}$ sebanyak 6 situs dan ketinggian 601 800 mdpl sebanyak 5 situs. Namun sayangnya penelitian ini masih belum dapat mengidentifikasi pusat-pusat budaya yang disebutkan dalam berbagai prasasti.

Sementara itu, sebagai bagian dari pelestarian cagar budaya, tulisan ini menggunakan dua peraturan perundangan utama untuk menjadi landasan hukumnya, yaitu UndangUndang Nomor 5 Tahun 2017 tentang Pemajuan Kebudayaan dan Undang-Undang Nomor 11 Tahun 2010 tentang Cagar Budaya.

\section{HASIL DAN PEMBAHASAN Deskripsi Situs}

Terdapat lima situs yang dapat dikategorikan sebagai tinggalan masa klasik Hindu/Buddha, yaitu Lokasi Yoni di Brongsongan, Lokasi Candi Dipan, Lokasi Candi Bowongan, Lokasi Candi Samberan, dan Lokasi Yoni di Plandi, dan satu situs yang masuk kategori masa kolonial, yaitu Lokasi Makam Belanda (Kerkhoff) Bojong di Mendut Berdasarkan informasi dari Dinas Pendidikan dan 
Kebudayaan Kabupaten Magelang, kelima situs klasik Hindu/Buddha tersebut belum ditetapkan sebagai cagar budaya, sedangkan Lokasi Makam Belanda (Kerkhoff) Bojong sudah ditetapkan sebagai cagar budaya melalui Keputusan Bupati Magelang Nomor: 180.182/317/KEP/23/2015 tentang Penetapan Bangunan dan Situs Cagar Budaya di Kabupaten Magelang.

\section{Lokasi Yoni di Brongsongan}

Lokasi yoni ini berada sekitar $\pm 2 \mathrm{~km}$ sebelah barat Candi Borobudur. Keberadaan situs pertama kali dicatat pada tahun 1899 didalam laporan yang disusun oleh Van Aalst berjudul Opgaven omtrent verschillende Hindoe-oudheden, voorkemde in de Controle-afdeling Prabalingga yang menyebutkan dengan nama "Kanggan", dimungkinkan karena letaknya yang berada di dekat dusun Kanggan. Knebel (1911) menyebut situs ini sebagai "Srianom" karena lokasinya berada di wilayah desa Srianom yang sekarang telah berubah nama menjadi Wringinputih (Sub Konsorsium (1976: 35-6). Krom kembali menggunakan istilah "Sri-anom" untuk menyebut situs ini dalam ROD tahun 1914 dengan mencatat keberadaan dua buah yoni (Rapporten, 1914: 25). Tidak jauh dari lokasi ini terdapat situs lain bernama Kranggan dimana terdapat sebuah yoni, yang didekatnya ditemukan fragmen arca Siwa dan Ganesha yang kemudian disimpan di Borobudur (Rapporten, 1914: 26). Didekat temuan tersebut, terdapat sumuran yang berisi lempengan emas berisi mantram yang saat ini disimpan di Museum Nasional (Rapporten, 1914: 25).
Catatan berikutnya yang menyebutkan keberadaan situs ini terdapat di Arsip Pemugaran Candi Borobudur yang saat ini disimpan di Balai Konservasi Borobudur. Dalam arsip tersebut disebutkan bahwa pada tanggal 29 April 1971, penduduk setempat melaporkan temuan tiga buah arca, sebuah lingga, dua buah yoni, serta beberapa batu bata berukuran besar di sebuah sawa milik Sdr. Wirjosudiro yang terletak di Dusun Kanggan, Desa Wringinputih, Kecamatan Borobudur. Berdasarkan keterangan penemu, lingga telah diketahui keberadaannya beberapa tahun sebelum pelaporan tersebut dan disimpan di rumah seorang warga, sedangkan dua buah yoni telah lama diketahui keberadaannya di lokasi tersebut. Yoni ini kemungkinan adalah dua buah yoni yang dicatat oleh Krom pada tahun 1914. Berdasarkan laporan tersebut, petugas LPPN yang ditempatkan di Borobudur melakukan peninjauan pada tangga 4 Mei 1971, dan memutuskan pada hari berikutnya untuk membawa benda-benda tersebut ke kantor Proyek Pemugaran Candi Borobudur. Menindaklanjuti pelaporan ini, hadiah temuan diberikan kepada pelapor pada tanggal 30 Maret 1974. Dua buah yoni diputuskan untuk ditinggal di lokasi. Adapun deskripsi bendabenda temuan dijabarkan dalam paragraf dibawah.

Arca I terbuat dari batu andesit yang sangat porus, serta dalam keadaan patah di bagian pergelangan kaki, tetapi dapat disambung kembali. Memiliki tinggi 46,5 $\mathrm{cm}$ dengan tinggi seluruhnya beserta lapik $53 \mathrm{~cm}$. Tebal sandarannya $4,5 \mathrm{~cm}$. Bentuk muka berjenggot dan berkumis tebal, memiliki tiara, telinga panjang tetapi 
anting tidak jelas bentuknya, serta bagian belakang terdapat prabha dengan hiasan garis-garis. Lengan kanan dan kiri memakai kelat bahu yang sudah tidak teridentifikasi bentuknya, dengan tangan kanan memegang akshamala dan tangan kiri memegang kamandalu. Berperut besar dan memakai upawita, serta memiliki sikap pralamba. Diidentifikasi sebagai arca Agastya.
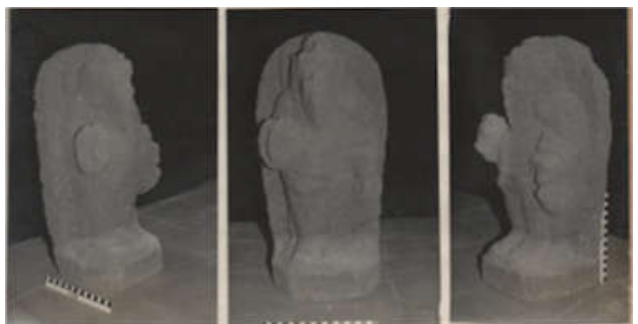

Gambar 2. Arca I Brongsongan, kemungkinan arca Agastya (Sumber: Arsip Pemugaran Candi Borobudur, 1971)

Arca II terbuat dari batu andesit, dan memiliki ukuran tinggi $43 \mathrm{~cm}$, tebal sandaran dan asana 6,5 $\mathrm{cm}$ dengan lebar $29 \mathrm{~cm}$. Memiliki ikonografi yang unik, berupa sandaran kepala, tiara bersusun, anting-anting bunga, kalung dengan liontin berbentuk bunga, kelat bahu berhias ratna, pergelangan tangan tanpa hiasan, tangan kanan dan kiri berposisi tengkurap diatas lutut, dan pergelangan kaki kanan memakai gelang tanpa hiasan. Posisi duduk dalam sikap dyana padasana, dengan penggambaran tiga ekor ular dibagian bawah yang menyembul keluar dibawah kedua kaki yang dilipat. Merupakan arca yang spesifik dan belum dapat teridentifikasi. Arca saat ini berada di Museum Borobudur.

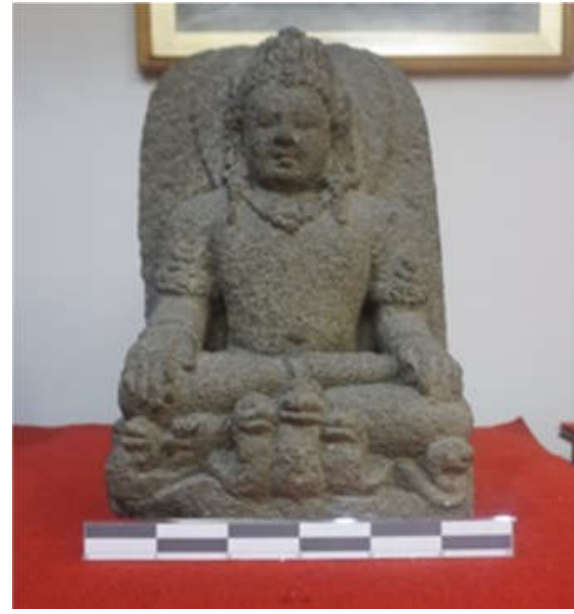

Gambar 3. Arca II Brongsongan (Sumber: Penulis, 2018)

Lingga terbuat dari batu andesit, berukuran tinggi $60 \mathrm{~cm}$, sisi bagian bawah (persegi) $20 \mathrm{~cm}$, sisi bagian tengan (persegi delapan) 20 $\mathrm{cm}$, diameter bagian atas $20 \mathrm{~cm}$. Berbentuk polos dan tidak memiliki ukiran ornamental. Saat ini berada di Museum Borobudur.

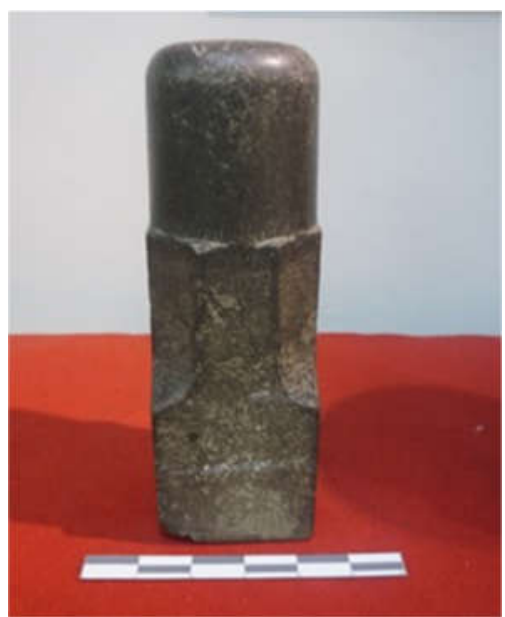

Gambar 4. Lingga Brongsongan (Sumber: Penulis, 2018)

Yoni I terbuat dari batu andesit, dengan ukuran bagian bawahnya mempunyai panjang 125 $\mathrm{cm}$ dan lebar $100 \mathrm{~cm}$, tinggi $108 \mathrm{~cm}$, sedangkan bagian atasnya memiliki panjang 125,5 cm dan lebar $120 \mathrm{~cm}$. Lubang dibagian tengah atas berukuran panjang $30 \mathrm{~cm}$, lebar 30 
$\mathrm{cm}$, dan dalam 62,5 cm. Cerat memiliki panjang $16,5 \mathrm{~cm}$, dan lebar ujung saluran $3 \mathrm{~cm}$. Hiasan dibawah cerat terdiri dari seekor garuda yang berdiri diatas kura-kura yang didukung oleh seekor naga. Kepala kura-kura telah patah. Ketika dilaporkan pada tahun 1971, yoni dalam kondisi terpendam tanah setengahnya dan sekitarnya telah ditanami tumbuhan. Diperkirakan keletakan yoni sudah tidak berada di posisi awalnya. Saat ini yoni berada di lokasi situs.

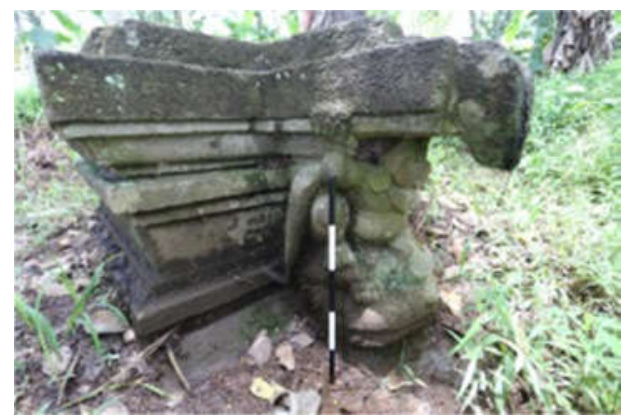

Gambar 5. Hiasan yoni I Brongsongan (Sumber: Balai Konservasi Borobudur, 2017)

Yoni II berukuran lebih kecil dari yoni I, dengan bagian bawahnya memiliki panjang $75 \mathrm{~cm}$ dan lebar $74,5 \mathrm{~cm}$, tinggi $71,5 \mathrm{~cm}$ serta bagian atasnya berukuran panjang $75 \mathrm{~cm}$ dan lebar $68 \mathrm{~cm}$. Lubang yoni berukuran panjang 23,5 cm, lebar 23,5 cm, dan dalam 48,5 cm. Bagian cerat telah patah dan hilang. Pada saat dilaporkan tahun 1971 berada dalam posisi terpendam didalam tanah sehingga diperkirakan posisinya sudah tidak asli. Saat ini yoni berada di lokasi situs.

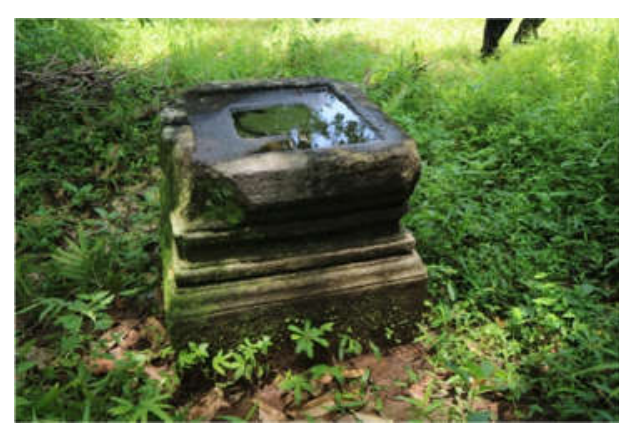

Gambar 6. Yoni II Brongsongan (Sumber: Penulis, 2019)

Penggunaan

nama

"Brongsongan" untuk situs ini dimulai pada tahun 1976 ketika dilakukan survei arkeologi di kawasan Borobudur dalam kegiatan Penataran Metode Arkeologi yang dilaksanakan oleh Sub-Konsorsium Sastra dan Filsafat, Departemen Pendidikan dan Kebudayaan, merujuk kepada nama lokasi dusun. Survei tahun 1976 mencatat keberadaan dua buah yoni dan tumpukan bata kuno di lokasi situs (Sub-Konsorsium, 1976: 34-5). Lahan disekitar benda temuan telah dialihfungsikan menjadi ladang ketela (Sub-Konsorsium, 1976: 34). Pada survei yang dilaksanakan pada tahun 2000, lahan situs digunakan sebagai tegalan yang ditanami pohon pepaya, kacang tanah, dan lombok, dengan dikelilingi persawahan dan perkampungan (Kasiyati dkk, 2000: 26). Saat ini lahan lokasi situs dimiliki oleh Bpk. Samhari yang merupakan warga dusun Brongsongan, dan merupakan tanah warisan keluarga. Ketika dilakukan wawancara dengan beliau, dituturkan bahwa di lokasi tersebut sering menemukan bata-bata kuno ketika sedang menggali tanah. Beliau juga mengingat adanya temuan 2 buah arca yang saat ini tidak diketahui keberadaannya. Ketika ditanyakan mengenai rencana beliau tentang lahan situs, disampaikan 
bahwa lahan tersebut terbukti tidak subur sehingga sudah tidak pernah diolah kembali. Mengingat pariwisata di kawasan Borobudur saat ini sudah semakin berkembang, beliau menyampaikan keinginan lokasi tersebut untuk dijadikan sebagai obyek wisata, sehingga dapat memberikan manfaat ekonomi bagi keluarganya. Sementara itu, walaupun dua arca spesifik belum teridentifikasi, keberadaan yoni, lingga dan agastya mengisyaratkan bahwa situs Brongsongan mempunyai latar belakang agama Hindu.

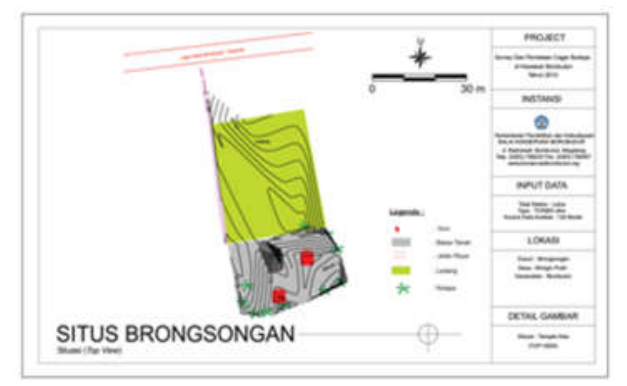

Gambar 7. Peta Situasi Lokasi Yoni di Brongsongan

(Sumber: Balai Konservasi Borobudur, 2013)

\section{Lokasi Candi Dipan}

Situs ini terletak sekitar $3 \mathrm{~km}$ di sebelah selatan Candi Borobudur. ROD tahun 1914 mencatat keberadaan arca Durga (Kasiyati, dkk, 2000: 25), yang saat ini belum diketahui keberadaannya kembali dan tidak diketahui bahan materialnya. Keberadaan berbagai temuan di situs ini kemudian dilaporkan dan dicatat kembali pada tahun 1974 didalam arsip yang saat ini tersimpan sebagai Arsip Pemugaran Candi Borobudur. Pada tanggal 1 Mei 1974, Sdr. Amat Dumar, karyawan Proyek Pemugaran Candi Borobudur, melaporkan bahwa Sdr. Dullah Kamari yang bermukim di dukuh Dipan menemukan sebuah arca dan sejumlah bata kuno. Berdasarkan laporan tersebut, peninjauan langsung dilakukan oleh Bpk. I.G.N. Anom didampingi Sdr. Katri Ismijarto.

Dalam laporan disebutkan bahwa arca terakota ditemukan oleh Sdr. Dullah Kamari ketika memperdalam parit di tepian bidang tanah milik Sdr. Alipawiro. Selain arca yang terbuat dari terakota, terdapat juga fragmen bata merah yang ditemukan bersamaan di kedalaman $\pm 1,5 \mathrm{~m}$. Arca ditemukan dalam keadaan membujur barattimur, dengan kepala berada di sebelah barat. Setelah digali dan diangkat, arca tersebut kemudian disimpan di rumah Sdr. Dullah Kamari. Ketika dilakukan peninjauan ke lapangan oleh tim dari Proyek Pemugaran Candi Borobudur, ditemukan juga fragmen arca berupa betis sebelah kanan yang merupakan bagian dari temuan arca terakota yang telah patah. Arca terakota tersebut mempunyai ukuran panjang $78 \mathrm{~cm}$, lebar $35 \mathrm{~cm}$, dan tebal $18 \mathrm{~cm}$, dengan bmemiliki mata ketiga di tengah kening, kedua mata melotot, taring dan gigi bagian atas terlihat, rambut ikal, anting berukuran besar yang berbentuk bunga, serta memiliki halo dibelakang kepala. Kalung memiliki hiasan liontin bunga dengan kerat bahu berhias bunga dan gelang di kedua pergelangan tangan, serta berperut buncit. Tangan kiri didepan dada sambil memegang semacam bunga, sedangkan tangan kanan berada didepan perut sambil membawa semacam buku. Arca berada dalam posisi berdiri, dengan posisi kaki kanan lurus, sedangkan kaki kiri ditekuk kedalam. Bagian bawah arca yang berisi betis kaki kanan kebawah telah patah dan hilang. Laporan peninjauan pada 
tahun 1974 mengidentifikasi arca ini sebagai Mahakala, tetapi identifikasi tersebut masih perlu dipertanyakan kembali. Disampaikan juga bahwa temuan ini merupakan temuan yang unik karena di daerah Jawa Tengah jarang ditemukan arca terakota dengan ukuran sebesar arca dari situs Dipan. Fragmen arca dan kaki tersebut kemudian dibawa ke kantor Proyek Pemugaran Candi Borobudur dan telah disambung kembali. Saat ini arca terakota disimpan di Balai Pelestarian Cagar Budaya Jawa Tengah.

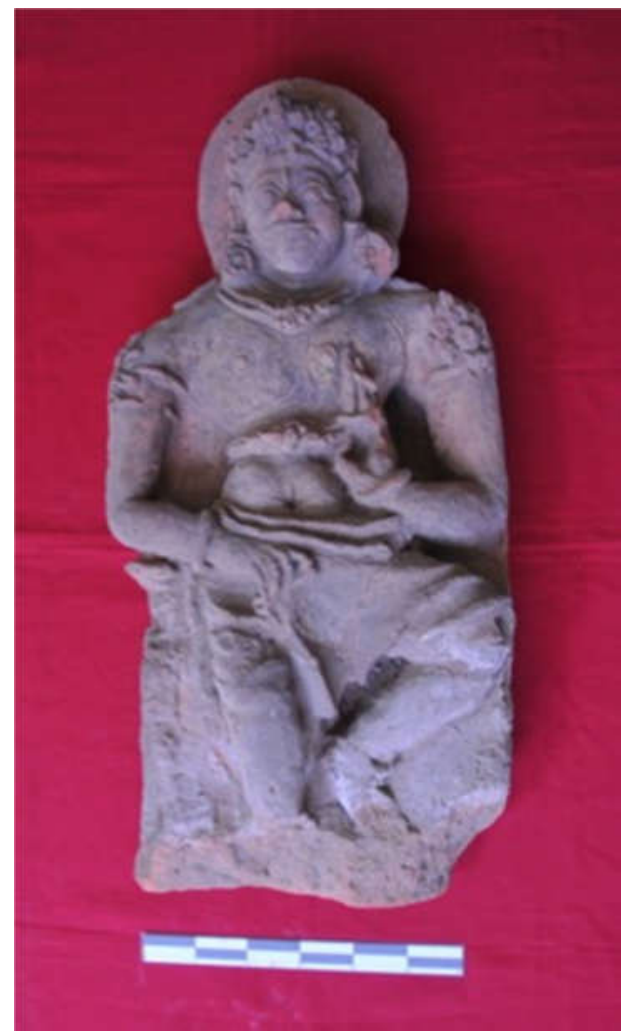

Gambar 8. Arca terakota, identifikasi awal sebagai Mahakala

(Sumber: A. Chabib Santoso, 2018)

Saat dilakukan peninjuan juga ditemukan sebuah antefiks bata di pojokan rumah Sdr. Siswopawiro, yang ditemukan pada tahun 1970 ketika sedang mencangkul tanah pada kedalaman $\pm 1 \mathrm{~m}$ di sawah miliknya yang berada di sebelah selatan ladang milik Sdr. Aliprawiro, dengan lokasi penemuan sekitar $7 \mathrm{~m}$ dari temuan arca terakota. Antefiks tersebut memiliki ukuran tinggi $29 \mathrm{~cm}$, lebar $25,5 \mathrm{~cm}$, dan tebal $26 \mathrm{~cm}$, dimana tebal lis bawahnya $9 \mathrm{~cm}$. Bagian sisi kanan antefiks telah pecah. Sementara itu, Survei tahun 1976 mencatat temuan bata kuno berbentuk persegi dan segi delapan dengan tinggi $16 \mathrm{~cm}$ dan mengerucut keatas. Selain temuan bata, tim juga mencatat keberadaan batu stupa berukir dengan ukuran tinggi padma $5 \mathrm{~cm}$, anda $18 \mathrm{~cm}$ dan harmika $5 \mathrm{~cm}$ (Sub-Konsorsium, 1976: 60). Batu ini kemungkinan telah tidak in situ lagi, dan ketika disurvei telah digunakan sebagai lumpang oleh penduduk setempat dengan sebutan "Watu Kenteng” (Sub-Konsorsium, 1976: 60). Tidak dijumpai dokumentasi foto dalam laporan survei tersebut. Sementara itu, survei pada tahun 2000 oleh tim Balai Konservasi Borobudur tidak mencatat temuan baru, dengan lahan lokasi situs pada saat itu difungsikan sebagai ladang singkong (Kasiyati, dkk, 2000: 25).

Pada tahun 2001, dilakukan penggalian arkeologis di situs Dipan oleh tim Balai Arkeologi Yogyakarta, yang diketuai oleh Drs. Baskoro Daru Tjahjono, dalam penelitian mengenai latar belakang pendirian candi bata di Jawa Tengah tahap II. Ekskavasi yang dilakukan menggunakan sistem test pit, dimana tim berhasil membuka sejumlah 13 parit, masing-masing berukuran 1 × 2 m (Tjahjono, 2001: 5). Dari penelitian tersebut ditemukan bahwa denah Candi Dipan berbentuk persegi dengan ukuran $5 \mathrm{x} 5 \mathrm{~m}$, dengan kemungkinan arah hadap ke timur (Tjahjono, 2001: 21). Struktur 
temuan ekskavasi mempunyai tinggi fondasi $30 \mathrm{~cm}$ terdiri atas 3 lapis bata, dengan dinding kaki diatas fondasi terdiri dari 6 lapis bata dengan tinggi $60 \mathrm{~cm}$, yang kemudian diinterpretasikan sebagai teras candi (Tjahjono, 2001: 21-2).

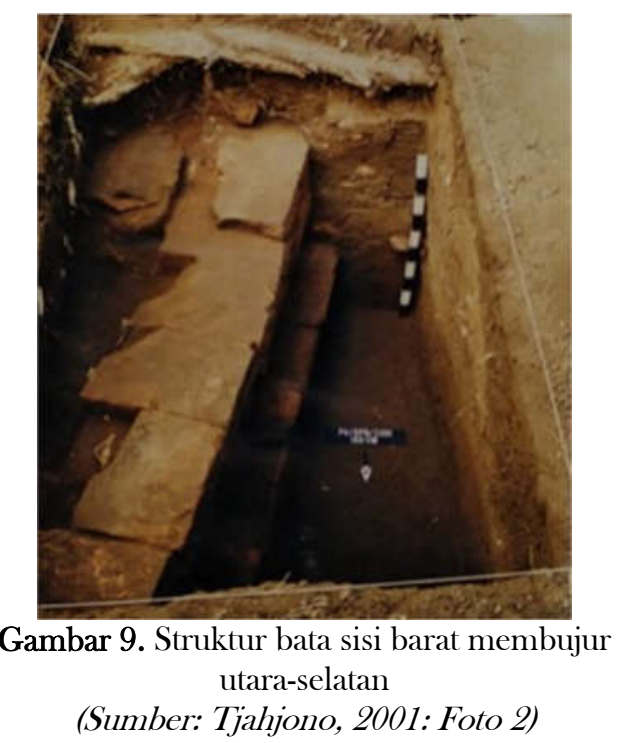

Selain temuan struktur, tim dari Balai Arkeologi Yogyakarta juga menemukan dua buah antefiks bata, fragmen pedupaan, dan stupa bata. Antefiks dan pedupaan disimpan di Museum Borobudur setelah ekskavasi (Tjahjono, 2001: 22). Stupa bata, menurut penuturan oleh Bpk. Basiron, salah satu pemilik tanah di situs Dipan, disimpan dirumahnya. Stupa ini kemudian diminta dan diserahkan kepada pengurus Vihara Mendut. Namun, informasi ini masih belum terkonfirmasi karena ketika dilakukan kunjungan lapangan oleh tim kajian pada bulan Oktober 2018 ke Vihara Mendut tidak menemukan stupa tersebut didalam area vihara yang dapat diakses oleh publik. Sementara itu, lahan lokasi Candi Dipan saat ini terletak di bidang tanah yang dimiliki oleh empat orang, yaitu
Bpk. Ahmadi, Bpk. Basiron, Bpk. Wiyono dan Bpk Priyono, yang merupakan tanah warisan keluarga. Lahan sekarang difungsikan sebagai ladang ketela, dengan struktur bata terpendam dan tidak tampak dari permukaan. Dengan temuan berupa 2 buah stupa kecil dari terakota, dapat disimpulkan bahwa Candi Dipan berlatar agama Buddha.

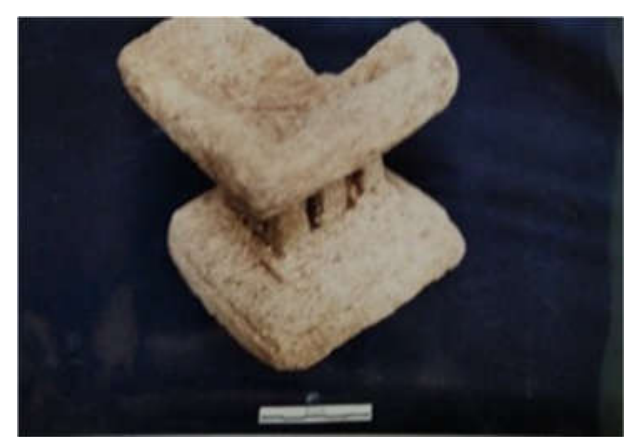

Gambar 10. Fragmen pedupaan terakota (Sumber: Tjahjono, 2001: Foto 5)

Untuk menegaskan kembali keletakan Lokasi Candi Dipan karena kondisinya sekarang yang tertutup tanah dan tidak ada penanda berupa artefak di permukaan, tim dari Balai Konservasi Borobudur melaksanakan ekskavasi pada bulan Oktober 2018. Kegiatan tersebut menemukan artefak baru yang mempertegas karakteristik situs ini sebagai struktur bata, yang terdiri dari fragmen stupa terakota, dua buah fragmen pecahan ukiran wajah, antefiks bata, serta sebuah bata yang diduga sebagai umpak yang ditemukan di dekat struktur teras candi. 


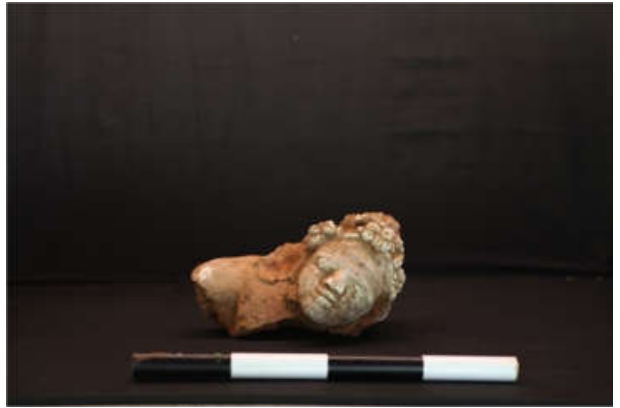

Gambar 11. Fragmen kepala arca terakota (Sumber: Balai Konservasi Borobudur, 2019)

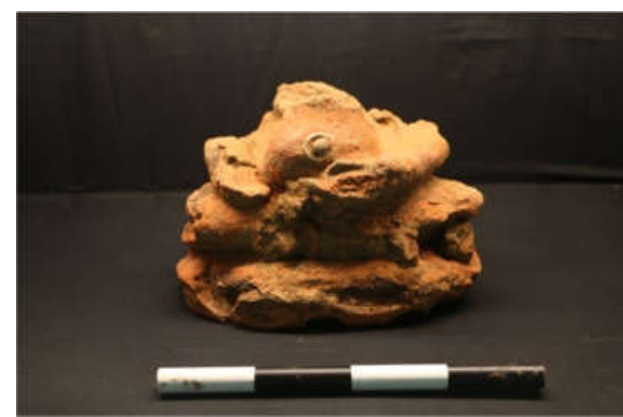

Gambar 12. Fragmen arca terakota (Sumber: Balai Konservasi Borobudur, 2019)

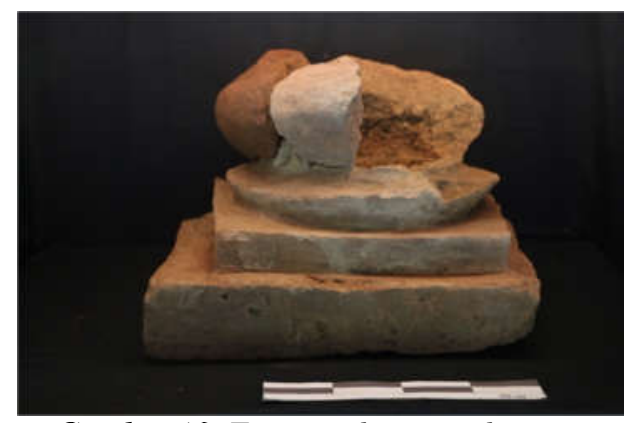

Gambar 13. Fragmen kemuncak stupa terakota

(Sumber: Balai Konservasi Borobudur, 2019)

\section{Lokasi Candi Bowongan}

Situs ini terletak sekitar $4 \mathrm{~km}$ sebelah barat laut Candi Borobudur. Laporan ROD tahun 1914 menyebutkan keberadaan dua buah patung Ganesha yang sudah rusak serta temuan bata. Dalam Laporan Singkat Peninjauan Kekunaan Didukuh Bowongan, yang saat ini tersimpan dalam Arsip Pemugaran Borobudur, disebutkan bahwa Sdr. Ujas melaporkan beberapa peninggalan purbakala di Dukuh Bowongan pada tanggal 12 Maret 1973, yang selanjutnya ditinjau langsung oleh Bpk. I.G.N. Anom dan Katri Ismijarto, dengan didampingi Sdr. Ujas pada tanggal 16 Maret 1973.

Temuan pertama berupa Yoni I terbuat dari batu andesit dan berukuran panjang $52 \mathrm{~cm}$, lebar 52 $\mathrm{cm}$ dan tinggi $42 \mathrm{~cm}$. Cerat dan ornamennya telah patah dan hilang. Pada saat peninjauan, yoni ini disimpan di pekarangan milik Sdr. Ngadelan. Dua sisi aus karena sering digunakan alas untuk mengasah pisau. Pada saat dilakukan survei oleh tim Balai Konservasi Borobudur pada bulan Oktober 2018, diketahui bahwa yoni ini masih berada di pekarangan rumah penduduk. Selain itu, yoni kedua, ditemukan di tegalan milik Ny. Nursahid dengan cerat menghadap ke utara. Terbuat dari batu andesit, yoni ini berukuran panjang $90 \mathrm{~cm}$, lebar $90 \mathrm{~cm}$, tinggi 60 $\mathrm{cm}$ dan panjang cerat $21 \mathrm{~cm}$. Hiasan dibawah cerat berupa garuda diatas kura-kura. Yoni ketiga yang ditemukan terbuat dari batu andesit, berukuran panjang $75 \mathrm{~cm}$, lebar 75 $\mathrm{cm}$ dan tinggi $62 \mathrm{~cm}$. Pada saat peninjauan, posisi yoni miring terpendam tanah sebagian sehingga hiasan cerat tidak terlihat.

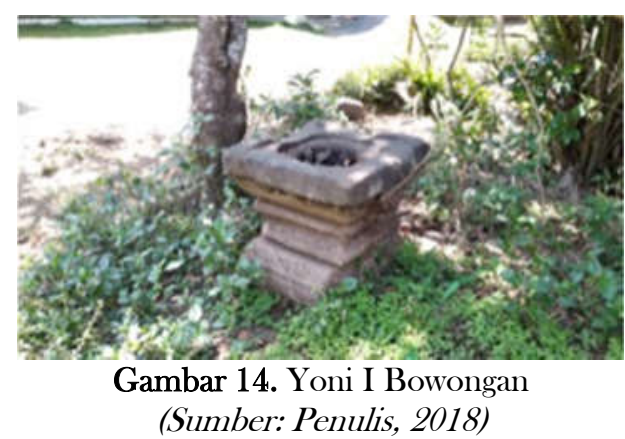

(Sumber: Penulis, 2018) 


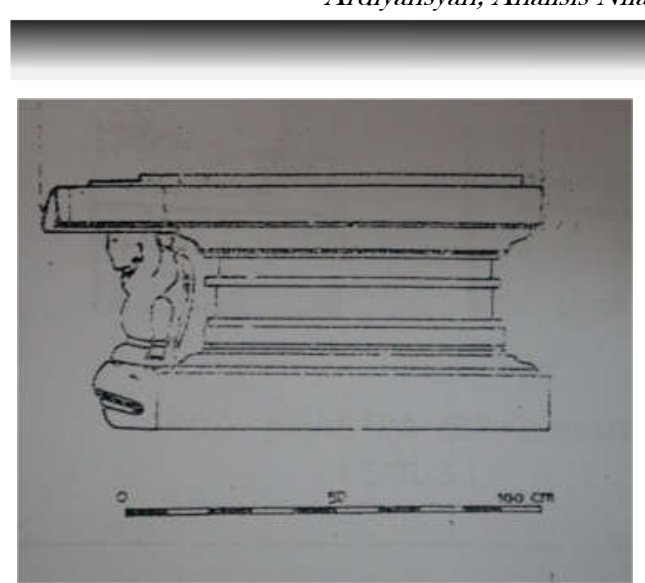

Gambar 15. Sketsa Yoni II Bowongan, tampak hiasan garuda dan kura-kura dibawah ceratnya

(Sumber: Sub-Konsorsium, 1976: Gambar II.26)

Sebuah arca tidak lengkap terbuat dari batu andesit, kondisi arca pada saat peninjauan di pekarangan Sdr. Ngadelan sudah dalam kondisi rusak sehingga sudah tidak dapat diidentifikasi. Kepala dan bahu kiri hilang, sedangkan kedua tangan, kaki dan talanya pecah. Saat ini arca tersimpan di kantor Balai Konservasi Borobudur. Sementara itu, arca Agastya ditemukan dalam kondisi baik, terbuat dari batu andesit dan dalam kondisi baik. Berukuran tinggi arca79 $\mathrm{cm}$, tinggi tala $16 \mathrm{~cm}$, tebal sandaran $7 \mathrm{~cm}$, dan lebar arca 16,5 $\mathrm{cm}$. Arca ini ketika ditinjau berada di pekarangan $\mathrm{Ny}$. Nursahid dan saat ini berada di Museum Borobudur. Menurut keterangan yang bersangkutan, arca ini ditemukan dibawah sebuah yoni di tegalan miliknya.

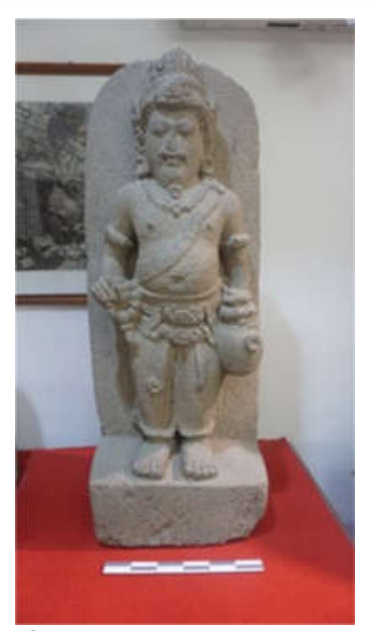

Gambar 16. Arca Agastya dari Lokasi Candi Bowongan

(Sumber: Penulis, 2018)

Baki perunggu berukuran garis tengah $48 \mathrm{~cm}$, tinggi bibir $1,5 \mathrm{~cm}$ dan tebal $0,5 \mathrm{~cm}$, ditemukan oleh Sdr. Djaelani. Baki ditemukan di kedalaman 50-60 cm, dimana pada bagian tengah muka terdapat gambar sangka diapit sulur-suluran yang dibatasi oleh dua lingkaran. Menurut laporan, baki kemudian dititipkan di kepala desa setempat. Sementara itu, pemilik tanah mengatakan bahwa baki ini ditemukan bersama benda lain berupa dua buah baki serupa, dua buah baki segi empat dengan tutup, dan satu kendi, yang kesemuanya kemungkinan terbuat dari bahan perunggu. Dua baki segi empat dan baki dalam kondisi rusak berat sehingga dianggap tidak dipakai dan tidak disimpan, sedangkan temuan dua baki bundar kemudian dijual ke sesama penduduk Borobudur.

Guci yang terbuat dari tanah liat tanpa glasir, ditemukan oleh Sdr. Sofyan. Guci ini berukuran tinggi 27 $\mathrm{cm}$, garis tengah badan $28 \mathrm{~cm}$, garis tengah mulut $10 \mathrm{~cm}$, dan garis tengah kaki $12 \mathrm{~cm}$, serta memiliki cerat yang unik karena sangat kecil dan pendek 
apabila dibandingkan dengan temuan guci dari tempat lain. Guci kemudian dititipkan ke kepala desa setempat.

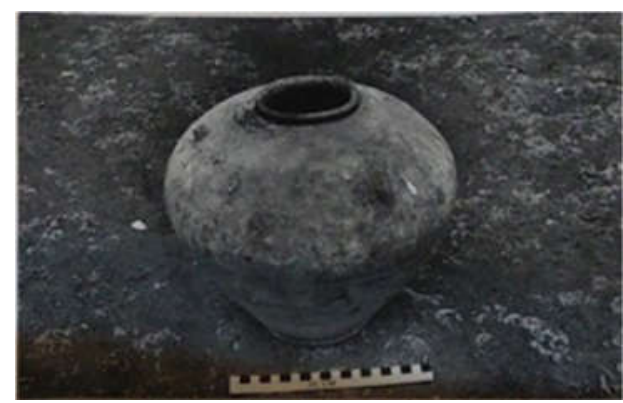

Gambar 17. Guci dari tanah liat (Sumber: Arsip Pemugaran Candi Borobudur SA.03)

Sementara itu, survei yang dilaksanakan pada tahun 1976 menemukan temuan berupa fragmen arca, pecahan gerabah, manik-manik, potongan perunggu, kerak besi, dan guci. Setelah dilakukan ekskavasi oleh Sub-Konsorsium Sastra dan Filsafat Departemen Pendidikan dan Kebudayaan pada tahun 1975 dan 1976 pada dua lokasi penggalian, ditemukan karakteristik bangunan suci keagamaan di lokasi pertama, sedangkan lokasi kedua memunculkan karakteristik pemukiman. Temuan ekskavasi pada lokasi pertama berupa sumuran candi ukuran $230 \quad$ x $230 \quad \mathrm{~cm}$ pada kedalaman $40 \mathrm{~cm}$, fragmen gerabah, dan fragmen bata. Pada lokasi kedua ditemukan kerak batu, fragmen besi, fragmen clupak, fragmen periuk, fragmen gerabah asing, dan sebaran arang. Di luar lubang galian lokasi kedua, ditemukan pecahan gerabah lokal, bola terakota, manik-manik, fragmen perunggu, dan sebaran arang. Sementara itu, dari berbagai temuan fragmen gerabah, pecahan wadah yang dapat direkonstruksi terdiri dari 2 tipe, sedangkan keseluruhan fragmen dapat diklasifikasikan kedalam 15 tipe yang terdiri dari 13 tipe terbuka dan 2 tipe tertutup (Sub-Konsorsium, 1976: 87). 11 tipe yang teridentifikasi memiliki kesamaan dengan tipe wadah yang ditemukan di Borobudur (SubKonsorsium, 1976: 87).

Survei pada tahun 2000 mencatat sebuah yoni tanpa cerat (dan masih digunakan sebagai alas mengasah pisau) dan struktur bata dari penggalian tahun 1975 (Kasiyati dkk, 2000: 28). Setelah survei yang dilaksanakan oleh tim Balai Konservasi Borobudur pada bulan Oktober 2018, diketahui bahwa lokasi situs yang berada di bidang tanah oleh Ibu Maryati telah disewakan untuk bahan material pembuatan bata. Dengan kondisi tanah yang telah digali sedalam kurang lebih $3 \mathrm{~m}$, struktur sumuran saat ini telah tidak ditemukan lagi. Yang masih terlihat adalah sebuah struktur bata yang terdiri dari tiga lapis dan sebuah struktur bata berbentuk undakan yang berjarak kurang lebih $150 \mathrm{~m}$ di antara keduanya. Walaupun situsnya telah rusak karena pabrik pembuatan bata, warga tidak berani mengambil batabata kuno karena takut kualat, sehingga dibiarkan saja berserakan di tanah atau biasanya ditumpuk menjadi satu. Sementara itu, sebuah yoni masih tersisa di sekitar situs, yang oleh warga sering disebut sebagai watu kenteng.

\section{Lokasi Candi Samberan}

Terletak sekitar $4 \mathrm{~km}$ sebelah barat laut Candi Borobudur, dalam JICA Final Report 1979 tercatat fragmen bata, tiga lapik arca, dan menurut laporan warga terdapat dua buah arca yang sekarang belum diketahui kembali keberadaannya 
(JICA Study Team, 1979: 71). Sementara itu pada tahun 2000, survei Balai Konservasi Borobudur mencatat keberadaan pecahan bata kuno yang berserakan, dua buah yoni dalam posisi terbalik, dan dua buah umpak yang telah menjadi fondasi rumah (Kasiyati, dkk, 2000: 28-9). Kedua yoni berbentuk persegi, dengan ukuran yoni pertama adalah $97 \mathrm{~cm}$ dan ukuran yoni kedua adalah $15 \mathrm{~cm}$. Ketika pemilik bidang tanah, Bpk Wahani, menggali tanah, ditemukan struktur bata yang kemudian dilanjutkan dengan survei dan ekskavasi yang dilakukan oleh tim Balai Arkeologi Yogyakarta pada tahun 2002, yang dipimpin oleh Baskoro Daru Tjahjono, sebagai bagian dari penelitian berjudul Latar Belakang Pendirian Candi Bata di Jawa Tengah Tahap III. Sayangnya tidak banyak informasi yang disebutkan dalam laporan penelitian tersebut.

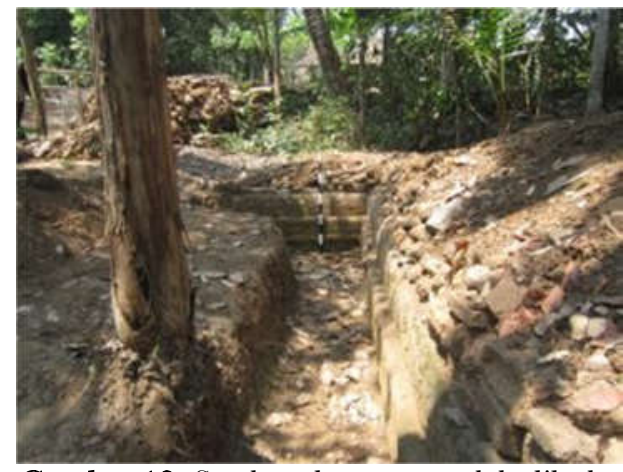

Gambar 18. Struktur bata yang telah dibuka oleh tim Balai Arkeologi Yogyakarta tahun 2002

(Sumber: Balai Konservasi Borobudur, 2003)

Dahulunya pekarangan lokasi situs ini dikenal sebagai candi wurung dan dianggap warga sebagai daerah yang angker karena adanya berbagai cerita mistis seperti kesurupan. Walaupun demikian, sejarah lisan yang dituturkan oleh keluarga Bpk.
Wahani menunjukkan kedekatan personal warga sekitar dengan tinggalan purbakala di Lokasi Candi Samberan. Umpak yang tadinya berada diatas struktur bata dahulu sering digunakan untuk menumbuk singkong untuk membuat gethuk karena bentuknya yang seperti lumpang. Sebuah arca dulu juga berada di sungai yang berada di dekat dengan situs, yang sering menjadi teman bermain para anak-anak pada saat itu. Dituturkan juga bahwa terdapat dua buah umpak yang dipindahkan ke masjid untuk digunakan sebagai tadah jatuhnya air talang. Umpak kemungkinan masih berada di masjid tapi sudah terpendam fondasi baru. Ketika dan beberapa saat setelah ekskavasi dilakukan oleh tim Balai Arkeologi Yogyakarta, temuan struktur ini sempat menjadi obyek wisata karena menjadi tontonan warga sekitar yang penasaran ini melihat temuan candinya. Keluarga Bpk. Wahani menuturkan bahwa pada saat itu mendapatkan pemasukan tambahan dengan berjualan kepada warga yang datang berkunjung. Menurut penuturan mereka juga, tim ekskavasi kemudian menitipkan struktur dan umpak yang berada di atas struktur untuk dirawat dan nantinya akan mendapatkan gaji setiap bulannya dari pemerintah. Walaupun cerita ini perlu dikonfirmasi kembali, dapat dipastikan bahwa tidak ada juru pelihara yang telah diangkat dan ditempatkan di Lokasi Candi Samberan, baik itu berasal dari keluarga Bpk. Wahani ataupun dari warga lain. Namun, setelah mendapat pesan untuk merawat situs, umpak dipindahkan oleh Bpk. Wahani kedekat rumahnya agar tidak hilang Pada saat ini kemungkinan struktur 
bata luasannya berada di tanah milik Bpk Wahani, Bpk. Wakidi, dan Bpk. Rabun. Kedepan, keluarga Bpk. Wahani menyampaikan keinginan untuk ekskavasi agar diteruskan kembali dan struktur yang tampak dapat dimanfaatkan sebagai obyek wisata sehingga dapat memberikan manfaat ekonomi kepada mereka yang tinggal di sekitar situs.

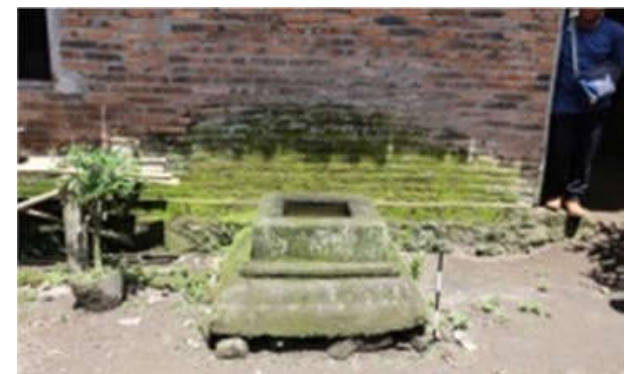

Gambar 19. Umpak yang berada di sebelah rumah Bpk. Wahani

(Sumber: Balai Konservasi Borobudur, 2017)

\section{Lokasi Yoni di Plandi}

Pada laporan ROD tahun 1914, tercatat sebuah batu yoni yang amat besar (Rapporten, 1914: 2). Sementara itu survei JICA pada tahun 1978-9 mencatat sebuah yoni dan fragmen bata (JICA Study Team, 1979: 71). Yoni mempunyai cerat menghadap ke utara dan berukuran $120 \times 111 \mathrm{~cm}$, dengan tinggi yang tidak diketahui karena sebagian masih terpendam tanah. Hiasan bawah cerat berupa pahatan garuda berada diatas punggung kura-kura.

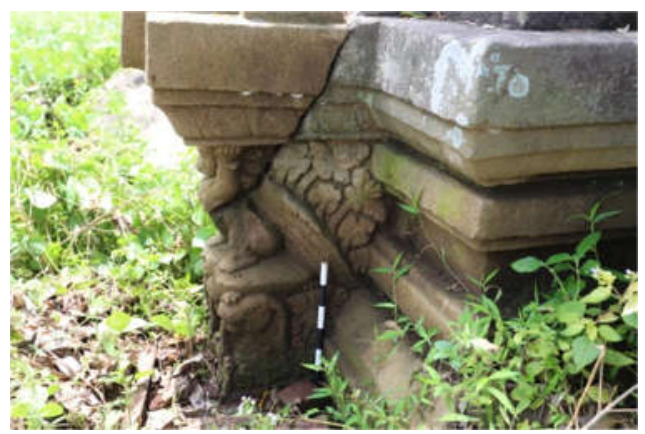

Gambar 20. Hiasan garuda, kura-kura dan naga dibawah cerat yoni Plandi (Sumber: Balai Konservasi Borobudur, 2017)

Pada tahun 2016, warga melaporkan keberadaan prasasti didekat lokasi yoni. Prasasti ini berukuran tinggi $50 \mathrm{~cm}$, lebar atas 38 $\mathrm{cm}$, lebar bawah $41 \mathrm{~cm}$ dan tebal 9,5 $\mathrm{cm}$, dengan bagian depan berisi 8 baris dan bagian belakang lima baris yang telah aus. Prasasti saat ini disimpan di kantor Balai Pelestarian Cagar Budaya (BPCB) Jawa Tengah. Pembacaan dan alih bahasa prasasti dibawah dikutip dari Anissa Y. Affida (2018: 267).

Bagian depan

1) Selamatlah tahun saka yang telah berjalan $7 \ldots$

2) 91, bulan marggasira

3) hari ke-7 paro gelap

4) hari Was Kaliwuan Buda ketika ra

5) kai sirat dan guru pendeta kuil

6) nya (yang berada di) kiri, membatasi sima sawahnya

7) para rãma di . . .

8) pa na_san ka

Bagian belakang telah aus sehingga tidak dapat terbaca menjadi sebuah kata lengkap.

Prasasti ini menginformasikan peresmian sima berupa sawah yang diinaugurasi pada tanggal 30 November 869 M oleh Rakai Sirat atau Sirak dan guru pendeta kuil (Affida, 2018: 267). Berdasarkan keterangan dari Titik Handayani selaku Kepala Seksi Sejarah, Museum dan Purbakala, Dinas Pendidikan dan Kebudayaan Kabupaten Magelang, bidang tanah Lokasi Yoni di Plandi tidak pernah dibayarkan pajaknya sehingga diasumsikan telah dimiliki oleh negara. Juru pelihara, atas nama 
Ibu Siti Bachriyah, juga telah diangkat dan dikelola oleh Dinas Pendidikan dan Kebudayaan. Sementara itu, oleh warga sekitar situs ini sering disebut sebagai candi wurung, dan karena dianggap sakral, tidak ada yang berani mengakui tanah di sekitar situs sebagai miliknya karena takut kualat.

\section{Lokasi Makam Belanda (Kerkhoff) Bojong di Mendut}

Situs ini saat ini berada didalam pemakaman umum yang masih berfungsi yang berada di Kelurahan Mendut, Kabupaten Magelang. Dituturkan oleh Bpk. Andreas Sutoyo and Ibu Maria Theresa Karni, keluarga yang dituakan oleh masyarakat yang tinggal di sekitar Kerkhoff, keberadaan makam dari masa Hindia Belanda ini tidak dapat dilepaskan dari keberadaan sekolah Katolik putri yang pernah berdiri di sebelah Candi Mendut. Keberadaan sekolah ini pernah disebutkan oleh Groneman dalam bukunya berjudul Ruins of Buddhistic Temples in Progo Valley yang diterbitkan pada tahun 1912 (Groneman, 1912: 13). Sejarah pendirian sekolah Katolik putri di Mendut merupakan inisiatif dari misi Jesuit di Jawa yang dilakukan oleh Rm. Petrus Hoevenaars SJ dan Rm. G.J.M. van Lith SJ. Menurut sejarah lisan yang dituturkan oleh Bpk. Mujiono dan Sugito dari Museum Misi Muntilan, setelah sampai di pulau Jawa pada tahun 1896, Romo Hoevenaars mendirikan sekolah putri di Mendut, sedangkan Romo van Lith membuat sekolah putra di Muntilan. Lokasi sekolah sengaja dipilih di daerah pedesaan, dan bukan perkotaan, untuk menghindari konflik dengan Calvinisme (Kristen Protestan) yang lebih dipilih sebagai agama resmi keluarga kerajaan Belanda, dan juga telah melaksanakan misi agama di berbagai kota di wilayah Hindia Belanda. Pada tahun 1904, Romo Hoevenaars dipindah ke Cirebon, terutama karena sering berbeda pandangan dengan Romo van Lith dan diganti oleh Rm. Johannes Aloysius Schrader SJ (Steenbrink, 2007: 378). Romo Schrader sendiri meninggal pada tahun 1905 dan dimakamkan di Kerkhoff Mendut. Saat ini makam tersebut merupakan makam tertua di lokasi Kerkhoff dan mempunyai kekhasan karena posisi kepala jenazah berada di sebelah selatan, sedangkan makam-makam yang lain mempunyai posisi kepala di sebelah utara.

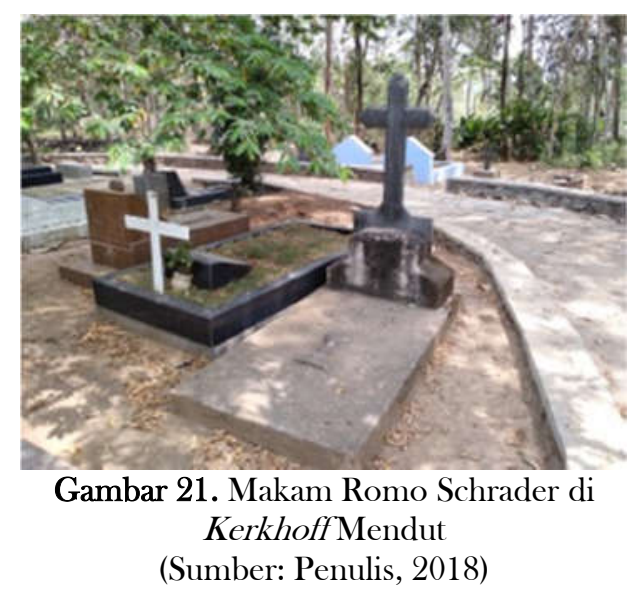

Karena didirikan bersamaan dengan sekolah putra di Muntilan, sekolah putri Mendut memiliki kedekatan dengan sekolah yang dibuat oleh Romo van Lith tersebut. Setiap bulan secara rutin diadakan pertemuan antara siswa putri dari Mendut dan siswa putra dari Muntilan dengan lokasi ditentukan secara bergiliran (Iswanti, 2008: 95-6). Kegiatan ini dapat dikatakan merupakan ajang perjodohan yang 'dicomblangi' oleh para romo dan 
suster. Salah satu tokoh nasional yang mendapatkan pasangan istri dari kegiatan ini, menurut penuturan dari Bpk. Sugito, adalah Ignatius Joseph Kasimo Hendrowahyono (atau lebih dikenal sebagai IJ Kasimo) yang merupakan lulusan sekolah putra Muntilan dan pendiri Partai Katolik. Ketika sekolah putra Muntilan dapat bertahan dari berubahnya keadaan sosial politik dari masa kolonial ke era setelah kemerdekaan, sekolah putri Mendut mengalami kemunduran dan perlahan hilang dari ingatan masyarakat umum karena, menurut penuturan dari Bpk. Sutoyo dan Ibu Karni - yang kemudian dikonfirmasi oleh Bpk. Sugito, bangunannya dihancurkan oleh penduduk ketika terjadi agresi militer II pada tahun 1948. Seperti sekarang kita ketahui bersama, periode setelah kemerdekaan Indonesia, yang sering disebut sebagai "Masa Bersiap" dalam periodisasi sejarah Belanda, menimbulkan banyak korban dari komunitas Belanda serta bangunanbangunan yang terasosiasi dengan mereka. Oleh karena bangunannya tidak dapat digunakan lagi, sekolah kemudian dipindah ke Ambarawa. Masih terkait dengan pemindahan ini, makam tiga orang suster di Kerkhoff Mendut kemudian dipindah juga ke Ambarawa. Karena penghancuran tersebut, misa kemudian dilaksanakan di Balai Paroki. Sejak tahun 1955, Kapel Santo Paulus didirikan di depan lokasi sekolah putri Mendut, yang dulunya merupakan lokasi Sekolah Rakyat (SR) putra. Kapel ini kemudian direnovasi dan diperluas menjadi Gereja Sapta Duka Bunda Maria dengan dukungan dari perkumpulan alumni siswi sekolah putri Mendut pada tahun 1995. Sementara itu, saat ini sebagian lokasi sekolah putri Mendut telah dibangun menjadi Vihara Mendut, sedangkan bagian selatannya telah dimiliki oleh warga perseorangan. Sebuah gerbang masih tersisa yang dituturkan oleh Bpk. Sutoyo dan Ibu Kasni masih berbentuk seperti aslinya.

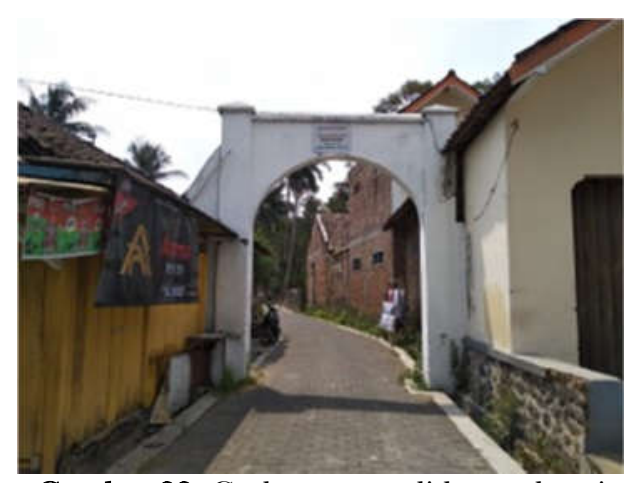

Gambar 22. Gerbang yang diduga sebagai bagian dari sekolah putri Mendut

(Sumber: Penulis, 2018)

Saat ini Kerkhoff Mendut dikelola dan dirawat oleh pengurus makam yang berada dibawah Paroki Borobudur yang termasuk kedalam Keuskupan Semarang. Paroki Borobudur berkedudukan di Gereja Santo Petrus, Kecamatan Borobudur, Kabupaten Magelang. Pada awalnya, Kerkhoff hanya dapat digunakan oleh masyarakat yang tinggal disekitar Mendut, namun mulai tahun 2000, pemakaman ini dibuka untuk masyarakat dari luar Mendut oleh Romo Adi Wardoyo. Akan tetapi, seperti dituturkan oleh Bpk. Sutoyo, masyarakat Mendut masih mendapatkan keistimewaan berupa hak untuk memesan lokasi makam, seperti yang telah dilakukan oleh Bpk. Sutoyo yang telah memesan lokasi disamping makam orang tuanya. Bpk. Sutoyo sendiri pada awalnya bukan merupakan penduduk Mendut tetapi berasal dari daerah Sendangsono, yang juga merupakan 
asal dari istrinya, yaitu Ibu Kasni. Ketika melihat sejarah perkembangan Katolik dan misi Jesuit di Magelang, maka segitiga Muntilan-MendutSendangsono tidak dapat dipisahkan karena di Sendangsono pernah terjadi pembaptisan 171 orang pada tanggal 14 Desember 1904, seperti dituturkan oleh Bpk. Mujiono dan diinformasikan melalui Museum Misi Muntilan. Oleh karena itu, beberapa saat kemudian sebuah petilasan dibangun di Sendangsono untuk memperingati pembaptisan tersebut. Diceritakan oleh Bpk. Sutoyo, beliau diadopsi oleh keluarga Bpk. Yuventius Sastrosuharyo karena bapak kandungnya meninggal dunia ketika beliau berusia 3 tahun. Mengikuti keluarga tersebut, yang juga merupakan bagian dari gereja di Mendut pada saat itu, Bpk. Sutoyo mulai tinggal di daerah Mendut sampai dengan sekarang. Sejarah keluarga Bpk. Sutoyo ini menggambarkan salah satu contoh kedekatan personal dan spiritual dari warga yang tinggal di sekitar Kerkhoff Mendut. Mereka juga secara rutin menggelar misa arwah di minggu pertama November yang dihadiri oleh masyarakat Katolik di Magelang secara umum. Di sisi lain, Seminari Mertoyudan juga menyelenggarakan misa arwah setiap tanggal 2 November dengan lokasi bergiliran di dua tempat, yaitu di Kerkhoff Mendut dan di Kerkhoff Muntilan, sebagai penghormatan bagi penyebaran agama Katolik melalui pendirian sekolah di dua lokasi tersebut. Sementara itu, bagi para alumni sekolah putri Mendut, beserta keturunannya, keberadaan Kerkhoff Mendut merupakan penanda, sekaligus jembatan nostalgia, masa lalu dimana saat ini mereka masih rutin mengadakan reuni setiap 3 tahun, walaupun menurut keterangan Bpk. Sutoyo, lokasi reuni ini tidak lagi dilakukan di Mendut dengan alasan usia. Imaji tentang sekolah putri Mendut juga menjadi inspirasi, sekaligus latar belakang, dari sebuah novel trilogi yang ditulis oleh Y.B. Mangunwijaya berjudul Rara Mendut.

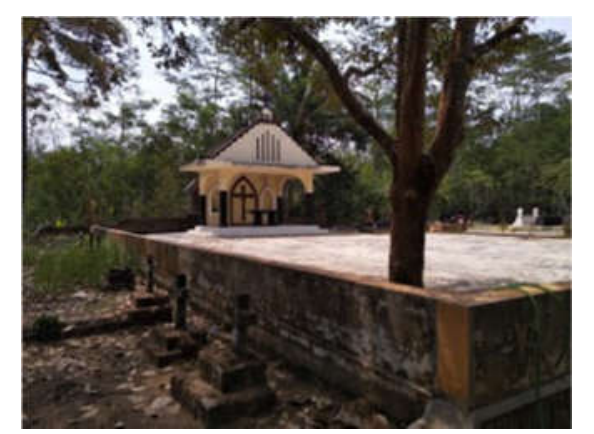

Gambar 23. Lokasi pelaksanaan misa arwah di dalam Kerkhoff Mendut

(Sumber: Penulis, 2018)

Kerkhoff Mendut telah ditetapkan sebagai Cagar Budaya melalui Keputusan Bupati Magelang Nomor: $\quad 180.182 / 317 / K E P / 23 / 2015$ tentang Penetapan Bangunan dan Situs Cagar Budaya di Kabupaten Magelang, dengan nama resmi Kompleks Makam Kerkhoff. Sesuai dengan keputusan tersebut, situs ini mempunyai luas lahan sebesar 100 $\mathrm{m}^{2}$. Didalam naskah rekomendasi oleh Tim Ahli Cagar Budaya Kabupaten Magelang, disebutkan bahwa makam tertua bernisan tahun 1905 yang merupakan makan Romo Pioe Monoriae, yang kemungkinan didasarkan oleh penyebutan masyarakat sekitar terhadap makam Romo Schraeders. Penyebutan "Pioe Monoriae" sendiri kemungkinan berasal dari tulisan paling atas di makam Romo Schrader (yang lebih tepatnya tertulis "Piae Memoriae") yang dalam Bahasa Inggris diartikan 
sebagai "In Memoriam". Sementara itu, lampiran keputusan bupati juga menyebutkan bahwa makam-makam yang berusia paling singkat berusia 50 tahun berjumlah 19 buah, sesuai dengan jumlah makam tua yang disebutkan dalam lampiran Keputusan Menteri Pendidikan dan Kebudayaan Nomor 286/M/2014 tentang Satuan Ruang Geografis Borobudur sebagai Kawasan Cagar Budaya Peringkat Nasional, dengan berangka tahun antara 1905 sampai dengan 1951. Akan tetapi ketika tim kajian melakukan survei lapangan pada Oktober 2018, tim hanya dapat mengonfirmasi sembilan buah makam berdasarkan adanya tahun ketika dimakam yang ditulis di nisan. Kesembilan makam tersebut adalah:

1. R.P. Joh. Aloys. Schraeders S.J. (16 Desember 1905)

2. Marta Lauw (18 Mei 1951)

3. Barbara Tangiting (20 Agustus 1927)

4. Maria Lauw (30 Agustus 1936)

5. Magdalena Lauw (19 Oktober 1938)

6. Anna Lauw (11 Februari 1939)

7. Joesop Lauw (15 Juni 1926)

8. Joesep Lauw (30 Agustus 1947)

Di lokasi dekat dengan kesembilan makam ini, terdapat barisan makam lain yang memiliki bentuk nisan yang serupa, sehingga dapat diduga berasal dari periode yang sama, namun tidak dapat dipastikan karena tidak memiliki angka tahun.

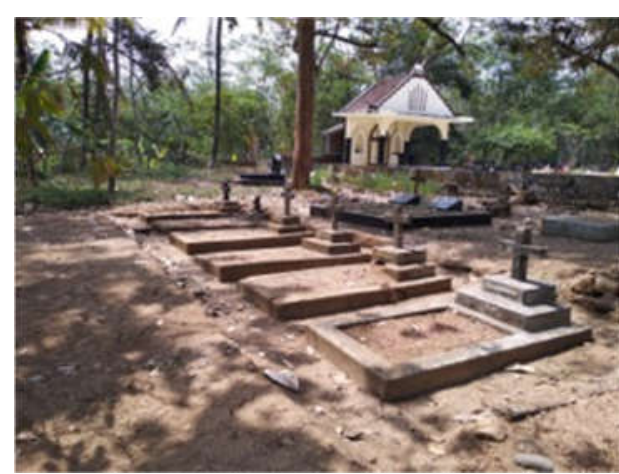

Gambar 29. Deretan makam yang sebagian besar berangka nisan dan bermarga Lauw (Sumber: Penulis, 2018)

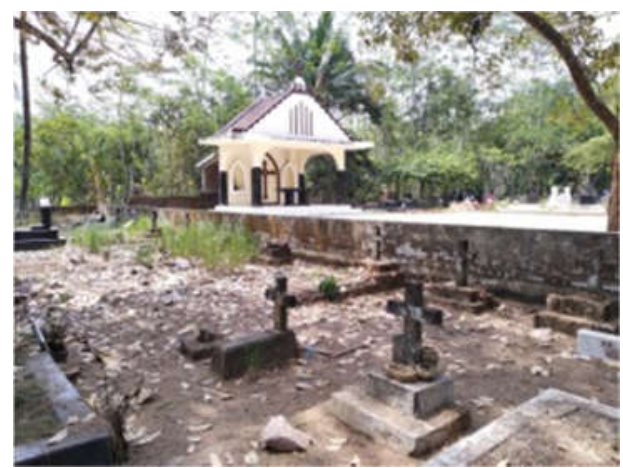

Gambar 30. Deretan makam tua yang diduga berusia paling singkat 50 tahun, tapi tidak memiliki angka nisan (Sumber: Penulis, 2018)

\section{Analisis Nilai Penting}

Berdasarkan deskripsi historis dan arkeologis enam situs diatas, maka nilai penting situs-situs tersebut sebagai bagian dari Kawasan Cagar Budaya dapat diuraikan sebagai berikut:

\section{Nilai penting bagi sejarah}

a. Lokasi Yoni di Brongsongan, Lokasi Candi Dipan, Lokasi Candi Bowongan, Lokasi Candi Samberan, dan Lokasi Yoni di Plandi, dalam perspektif historiografi ilmu purbakala Indonesia, merupakan representasi fisik dari sejarah perkembangan arkeologi dan ilmu konservasi di Indonesia (termasuk didalamnya perkembangan etika arkeologi 

dan metode pelestarian peninggalan purbakala),
keluarga Lauw, yang masih harus diteliti lebih lanjut lagi. khususnya di kawasan

Borobudur, dimulai dari usaha pendokumentasian oleh pemerintah Hindia Belanda melalui Komisi dan Dinas Purbakala, pelaksanaan Proyek Pemugaran Candi Borobudur oleh pemerintah Indonesia, dan berbagai penelitian oleh Balai Arkeologi. Hal ini terutama terjabarkan dalam laporan penemuan benda purbakala yang tersimpan di Arsip Pemugaran Candi Borobudur, dimana secara umum benda cagar budaya dilaporkan oleh masyarakat, ditinjau oleh petugas dari Proyek Pemugaran Candi Borobudur, diamankan dan diberikan kompensasi kepada para penemunya. Hal yang serupa masih dilakukan sekarang setelah secara legal formal diatur didalam UndangUndang No. 11 Tahun 2010 tentang Cagar Budaya

b. Lokasi Makam Belanda (Kerkhoff) Bojong di Mendut merupakan jejak sejarah perkembangan lansekap Borobudur dari periode akhir abad XIX M sampai dengan sekarang, khususnya mengenai sejarah misi Jesuit di Pulau Jawa, pergolakan dan revolusi kemerdekaan RI, serta perkembangan komunitas Katolik di kawasan Magelang. R.P. Joh. Aloys. Schraeders S.J., yang merupakan Romo kedua di Mendut, dimakamkan di situs ini. Selain itu, terdapat beberapa makam tua lainnya yang kemungkinan berasal dari
2. Nilai penting bagi ilmu pengetahuan

a. Lokasi Yoni di Brongsongan, Lokasi Candi Bowongan, dan Lokasi Yoni di Plandi memiliki kemiripan tinggalan yoni berupa hiasan dibawah cerat, yang menampilkan garuda dalam posisi jongkok, menopang cerat, diatas kurakura, yang berada diatas 3 ekor naga. Kombinasi hiasan ini cukup jarang ditemukan, dimana paling tidak terdapat 3 yoni lain yang memiliki kemiripan ikonografi ini, yaitu 2 buah yoni di Museum Nasional Jakarta dan 1 buah yoni di bekas RS Pugeran Yogyakarta (Haryono, 1980: 47). Pola yang teratur tersebut mengindikasikan adanya makna simbolis yang terkandung di unsur hiasannya. Kehadiran ketiga binatang ini kemungkinan

merepresentasikan cerita Amrtamanthana dan Garudeya, yang pada intinya bercerita tentang pencarian air suci amerta yang menjadi simbolisasi bagi air yang telah dibasuhkan ke yoni tersebut (Ibid.: 47).

b. Lokasi Yoni di Brongsongan dan Lokasi Candi Dipan memiliki gaya seni arca, khususnya ikonografi, yang khas dan spesifik yang jarang atau belum pernah ditemukan di tempat lain.

c. Lokasi Candi Dipan memiliki potensi penelitian yang besar bagi kajian arkeologis dan sejarah seni mengenai candi, 
relief, arca, dan hiasan ornamental bata, dimana hal ini masih jarang ditemui di kawasan Jawa bagian tengah. Selain itu, Candi Dipan mempunyai latar belakang agama Buddha, dimana selain Candi Borobudur, Candi Mendut dan Candi Pawon, jarang ditemukan di kawasan Borobudur.

3. Nilai penting bagi agama

a. Lokasi Yoni di Brongsongan, Lokasi Candi Dipan, Lokasi Candi Bowongan, Lokasi Candi Samberan, dan Lokasi Yoni di Plandi merupakan perwujudan fisik dari ekspresi keagamaan Hindu-Buddha pada periode abad VIII dan IX M di kawasan Borobudur. Temuan berupa lingga dan yoni mengindikasikan adanya pemujaan kepada dewa Siwa pada suatu waktu tertentu di lansekap masa lalu di Borobudur, sementara itu kehadiran unsur hiasan stupa di Lokasi Candi Dipan memberikan gambaran bahwa penyebaran agama Hindu dan Buddha di Borobudur terjadi pada waktu yang hampir bersamaan.

b. Lokasi Makam Belanda (Kerkhoff) Bojong di Mendut merupakan situs yang penting bagi, serta menjadi bagian penting dalam, kehidupan beragama kontemporer masyarakat Katolik di kawasan Magelang dan sekitarnya dengan berbagai kegiatan dan ritual yang sering dilakukan di situs tersebut. Situs ini masih aktif digunakan dan dianggap sebagai 'cikal bakal' perkembangan agama Katolik di Magelang. Oleh karena nilai penting tersebut, Kerkhoff Bojong menjadi tempat napak tilas, yang diwujudkan dalam misa arwah, bagi komunitas Katolik, baik yang berasal di Magelang maupun dari tempat lainnya di Indonesia.

4. Nilai penting bagi kebudayaan Lokasi Yoni di Brongsongan, Lokasi Candi Dipan, Lokasi Candi Bowongan, Lokasi Candi Samberan, Lokasi Yoni di Plandi, dan Lokasi Makam Belanda (Kerkhoff) Bojong di Mendut memiliki makna sosio-kultural dan spiritual yang penting melalui kedekatan personal warga yang tinggal di sekitar situs-situs tersebut, baik berupa penanda kenangan masa lalu, bagian dari sejarah kehidupan personal, ruang komunal masyarakat, serta bukti keterlibatan masyarakat dalam perkembangan ilmu kepurbakalaan di Indonesia. Beberapa situs candi mempunyai penyebutan lokal seperti candi wurung, watu kenteng, dan candi banon. Sementara itu beberapa narasumber yang diwawancara memberikan keterangan mengenai masa kecil mereka yang sering bermain di dekat dan dengan benda dan situs cagar budaya, walaupun mereka mungkin belum mengetahui makna arkeologis dari tinggalan-tinggalan tersebut. Beberapa kepercayaan magis juga muncul di masyarakat terkait keberadaan situs-situs ini yang menyimpan kekuatan supranatural yang tidak boleh diganggu. Hal ini merupakan bentuk kearifan lokal sehingga situs-situs tersebut secara umum masih terjaga 
keberadaannya karena masyarakat takut mendapatkan malapetaka apabila melakukan perilaku yang tidak baik.

\section{Pendekatan Strategi Pelestarian}

Pemilihan pendekatan strategi pelestarian harus mempertimbangkan sifat dinamis dari sebuah budaya beserta sistem, laku, dan obyeknya. Mempertimbangkan pelestarian dan memajukan obyek kebudayaan tidak hanya bertumpu kepada nilai dan fungsi masa lampaunya tetapi juga dengan memperhatikan dinamika laku dan pemaknaan sosial budaya di masyarakat. Di sisi lain, penyusunan strategi pelestarian di enam situs KCB Borobudur dilakukan tidak hanya dengan memperhatikan karakteristik lokal setiap situs namun juga dengan memandang mereka sebagai bagian yang tidak terpisahkan dari lansekap budaya yang telah ditetapkan sebagai KCB Borobudur. Selain itu, pendekatan strategi yang direkomendasikan mencoba untuk mengurangi pendekatan top-down dalam pengelolaan warisan budaya. Hal ini dikarenakan walaupun di satu sisi pendekatan ini baik dalam menekan pemerintah daerah dalam menerapkan kebijakan yang telah disusun, namun pada pelaksanaannya sistem ini menciptakan jarak antara warisan budaya dengan masyarakatnya karena tidak banyak memberikan ruang bagi partisipasi aktif dari penduduk lokal (Titik S., Dewi, dan Susanti, 2011: 53). Oleh karena itu, pendekatan strategi pelestarian yang diambil seyogyanya merupakan pendekatan pelestarian berbasis komunitas. Beberapa hal yang dapat dilakukan untuk memberikan ruang lebih besar untuk pelibatan masyarakat dalam pelestarian cagar budaya meliputi komunikasi dan kolaborasi, pengangkatan menjadi pegawai dan pelatihan, presentasi publik, wawancara dan sejarah lisan, wahana edukasi, dokumentasi melalui video dan foto, dan pembuatan suvenir situs oleh masyarakat (Moser et al, 2002: 229 dalam Smith dan Waterton, 2009: 16).

Pasal 3 Undang-Undang No. 11 Tahun 2010 tentang Cagar Budaya memberikan arahan bahwa salah satu tujuan pelestarian cagar budaya adalah untuk meningkatkan kesejahteraan masyarakat, dan dalam hal ini kesejahteraan tidak hanya dihitung melalui aspek ekonomi namun juga terkait dengan aspek psikologis. Beberapa kajian telah menunjukkan relasi yang positif antara keterlibatan dalam pelestarian heritage dengan tingkat kebahagian seseorang. Power dan Smyth (2016) menunjukkan bagaimana partisipasi seseorang sebagai bagian dari komunitas pelestari cagar budaya memberikan pengalaman yang positif dalam kehidupan mereka. Berbagai pengalaman teraputik yang tercatat adalah memiliki gairah, keingintahuan, kesenangan, pencapaian, kebanggaan, timbal balik, dan pertumbuhan, serta keterikatan, keterlibatan, dan kesejahteraan sosial (Power dan Smyth, 2016: 165). Selain itu, perlu diperhatikan juga terkait apresiasi bagi pemaknaan cagar budaya oleh masyarakat lokal yang kadang tidak sesuai dengan makna yang berikan oleh institusi resmi. Grimwade dan Carter (2000: 34) menyebut bahwa perhatian yang terlalu banyak bagi struktur fisik cagar budaya sebagai tinggalan masa lalu terkadang meminggirkan makna cagar 
budaya bagi masyarakat masa kini. Hal ini penting untuk diperhatikan sehingga dapat mempertahankan relevansi cagar budaya sebagai sebuah tinggalan masa lalu dengan kehidupan masyarakat kiwari.

Khusus untuk Lokasi Makam

Belanda (Kerkhoff) Bojong di Mendut, hasil kajian singkat ini menyarankan pendekatan strategi pelestarian secara pasif dengan memperkuat nilai dan narasi kehidupan beragama, tidak hanya terbatas pada agama Katolik, tetapi juga penyebaran dan perkembangan agama-agama yang lain, di kawasan Borobudur sejak jaman kolonial sampai dengan masa sekarang. Rekomendasi ini juga mempertimbangkan bahwa Kerkhoff Mendut merupakan living heritage dengan komunitas masyarakat pendukung yang cukup kuat. Sementara itu, untuk situs HinduBuddha dapat melibatkan masyarakat dalam pengamanan dan pemeliharaannya, misalnya dengan pelatihan metode perawatan cagar budaya secara sederhana untuk warga yang tinggal di sekitar situs. Contoh lain adalah dengan berpartisipasi dengan membentuk sebuah komunitas peduli cagar budaya.

\section{KESIMPULAN}

Penjabaran karakteristik setiap situs dan hasil analisis menunjukan kehadiran nilai penting bagi sejarah, ilmu pengetahuan, agama dan kebudayaan. Keberadaan nilai penting ini memberikan keterkaitan antara nilai penting kawasan Borobudur dalam level internasioal, nasional dan lokal. Sebagai sebuah warisan dunia yang telah diakui oleh UNESCO pada tahun 1991, Candi Borobudur, Candi Mendut dan
Candi Pawon pada khususnya dianggap sebagai sebagai sebuah mahakarya hasil kejeniusan manusia. Sebagai cagar budaya peringkat nasional, KCB Borobudur memberikan penekanan terhadap relasi antara Candi Borobudur, Candi Mendut dan Candi Pawon terhadap lansekap disekitarnya. Lansekap ini, baik dari aspek alam maupun budayanya, merupakan elemen yang tidak terpisahkan dalam pemaknaan nilai penting KCB Borobudur.

Hasil kajian menunjukkan bahwa situs-situs yang berada didalam KCB Borobudur juga mempunyai signifikansi lokal bagi masyarakat yang tinggal di kawasan Borobudur, baik itu di masa lalu maupun di masa sekarang. Keberadaan nilai penting yang saling beririsan dan berlapis ini memberikan alasan khusus untuk pelibatan aktif masyarakat yang bermukim di sekitar situs. Oleh karena itu, atensi khusus perlu diperhatikan dalam memberikan ruang yang lebih besar bagi suara masyarakat lokal dalam penciptaan narasi dan pelestarian nilai penting lansekap kawasan Borobudur.

\section{SARAN/ REKOMENDASI}

Terkait kesimpulan diatas, penulis merekomendasikan tindakantindakan berikut:

1. Penetapan Cagar Budaya oleh Bupati Magelang yang dikoordinasikan oleh Dinas Pendidikan dan Kebudayaan Kabupaten Magelang;

2. Sosialisasi usulan delineasi batas situs kepada pemerintah daerah, desa, dan masyarakat sekitar situs;

3. Penetapan delineasi setiap situs setelah dilakukan dan disetujui 
dalam konsultasi publik dengan mengutamakan peningkatan peluang kesejahteraan masyarakat;

4. Pembuatan pagar dan patok identitas di lokasi situs sebagai penanda batas situs;

5. Penunjukan juru pelihara yang bertanggung jawab untuk kegiatan perawatan sehari-hari sekaligus sebagai jembatan komunikasi antara pemerintah dan masyarakat sekitar;

6. Kajian arkeologis dan gaya seni tentang struktur candi berbahan bata yang masih belum banyak dikaji bagi gaya candi di wilayah Jawa bagian tengah;

7. Kajian budaya pemukiman masyarakat kuno di sekitar Borobudur, sebagai obyek kajian yang masih belum banyak diungkap;

8. Kajian perkembangan aktivitas keagamaan di masyarakat lansekap Borobudur pada masa kolonial sampai dengan sekarang;

9. Kajian sejarah lisan masyarakat terkait keberadaan situs-situs yang menjadi bagian dari KCB Borobudur;

10. Pembuatan papan informasi di setiap situs yang memberikan penjelasan tentang kaitan situs tersebut dengan Kawasan Cagar Budaya Borobudur, dengan mempertimbangkan narasi sejarah dan sosial yang telah dibangun oleh masyarakat;

11. Pelatihan metode sederhana perawatan cagar budaya sehingga masyarakat dapat berpartisipasi aktif dalam melestarikan situssitus di KCB Borobudur;

12. Pembuatan ruang pamer $\mathrm{KCB}$ Borobudur di Studio Sejarah
Restorasi

Candi

Borobudur/Museum Borobudur;

13. Inisiasi heritage day dengan target wisatawan minat khusus, dimana kegiatan one day tour dilaksanakan dengan mengunjungi situs-situs di KCB Borobudur diluar Candi Borobudur, Candi Mendut dan Candi Pawon dengan dipandu serta mendapatkan penjelasan oleh penduduk lokal;

14. Pembuatan virtual tour guide KCB Borobudur dengan menggunakan platform Borobudurpedia. 


\section{DAFTAR PUSTAKA}

\section{Arsip}

Laporan Penemuan Benda Purbakala Dokumentasi, Arsip Pemugaran Candi Borobudur Sa.03 1-2.

\section{Referensi}

Affida, Annisa Y. (2018). Prasasti dan Yoni di Tanah Plandi. Dalam Seminar Nasional Epigrafi: Penelitian Terkini Prasasti Indonesia, Yogyakarta 6-7 Maret 2018 (hlm. 265-73). Yogyakarta: Departemen Arkeologi UGM.

Degroot, Veronique. (2009). Candi, Space and Landscape: A study on distribution orientation and spatial organization of Central Javanese temple remains. Leiden: Sidestone Press.

Groneman, I. (1912). Ruins of Buddhist Temples in Progo Valley: Tyandis Barabudur, Mendut and Pawon (terjemahan oleh J.H.). Semarang: Druk van H.A. Benjamins.

Haryono, Timbul. (1980). Singa dalam Kesenian Hindu di Jawa Tengah. Berkala Arkeologi 1 (1), 42-51. https://doi.org/10.30883/jba.v1i1.275.

Holtorf, Cornelius. (2014). Public Perceptions of Heritage. Dalam C. Smith (ed) The Ecyclopedia of Global Archaeology (hlm. 3361-3366). New York: Springer.

Iswanti. (2008). Jalan Emansipasi: Perempuan Katolik Pionir dari Mendut 19081943. Yogyakarta: Penerbit Kanisius.

JICA Study Team. (1979). Republic of Indonesia Borobudur Prambanan National Archaeological Parks, Final Report, July 1979. Japan Internasional Cooperation Agency.

Kasiyati, Wiwit, dkk. (2000). Studi Isu Arkeologi pada Candi Borobudur. Magelang: Balai Studi dan Konservasi Borobudur.

Pearson, Michael dan Sharon Sullivan. (1995). Looking After Heritage Places: The Basics of Heritage Planning for Managers, Landowners and Administrators. Victoria: Melbourne University Press.

Power, Andrew dan Karen Smyth. Heritage, health and place: The legacies of local community-based heritage conservation on social wellbeing. Health and Place 39, 160-167.

Sektor Dokumentasi. Rapporten van den Oudheidkundigen Dienst in Nederlandsch Indie 1914 hal 211 s.d. 277.

Smith, Laurajane dan Emma Waterton. (2009). Heritage, Communities and Archaeology. London - New Delhi - New York - Surrey: Bloomsbury.

Smith, Laurajane. (2006). Uses of Heritage. London and New York: Routledge.

Steenbrink, Karel A. (2007). Catholics in Indonesia, 1808-1900: A Documented History. Volume 2: The Spectacular Growth of a Self Confident Minority, 1903-1942. Leiden: KITLV Press.

Sub Konsorsium Sastra dan Filsafat Departemen Pendidikan dan Kebudayaan. Laporan Penataran Metode Arkeologi: Jilid III Laporan Kerja Lapangan. Jakarta, Borobudur, Yogyakarta, 1975-1976. 
Tjahjono, Baskoro Daru. (2001). Laporan Penelitian Arkeologi Latar Belakang Pendirian Candi Bata di Jawa Tengah Tahap II. Yogyakarta: Balai Arkeologi Yogyakarta.

Tjahjono, Baskoro Daru. (2002). Laporan Penelitian Arkeologi Latar Belakang Pendirian Candi Bata di Jawa Tengah Tahap III. Yogyakarta: Balai Arkeologi Yogyakarta. 